\title{
ANALISIS FAKTOR-FAKTOR YANG MEMPENGARUHI KEPUTUSAN KONSUMEN \\ DALAM MEMILIH HOTEL MELALUI INTERNET MARKETING
}

Aris Susetyo, SE, MM

\begin{abstract}
Abstraksi
Tujuan penelitian ini untuk mengetahui pengaruh tingkat keputusan konsumen dalam memilih hotel melalui internet marketing baik secara parsial maupun simultan. Penelitian ini dilakukan di Hotel Candisari Karanganyar Kebumen. Penelitian ini dengan explanatory research, jumlah responden sebanyak 100 responden dan penentuan sampel menggunakan non-probability sampling-insidental sampling, yaitu teknik penentuan sampel berdasarkan kebetulan, yaitu siapa saja yang secara kebetulan/incidental bertemu dengan peneliti dapat digunakan sebagai sampel, bila dipandang orang yang kebetulan ditemui itu cocok sebagai sumber data. Hasil penelitian menunjukkan bahwa secara simultan (bersama-sama) variabel Karakteristik Individu, Gaya Hidup, Persepsi, Situasi berpengaruh terhadap Keputusan Konsumen Dalam Memilih Hotel Melalui Internet Marketing dan secara parsial variabel X Karakteristik individu,Gaya Hidup,Persepsi tidak mempunyai pengaruh yang signifikan, sedangkan Situasi mempunyai pengaruh yang signifikan terhadap Keputusan Konsumen Dalam Memilih Hotel Melalui Internet Marketing.
\end{abstract}

Kata kunci: Tingkat Keputusan Konsumen, Internet Marketing.

\section{PENDAHULUAN}

Perpindahan atau mobilitas antara daerah pada umumnya diakibatkan oleh beberapa sebab seperti untuk keperluan wisata, keperluan pekerjaan ataupun dalam kepentingan keluarga. Keperluan pekerjaan yang semakin kompleks dan jaringan antar pelaku usaha yang semakin luas yang mengharuskan kunjungan atau pertemuan bisnis antar pelaku menjadikan mobilitas menjadi suatu bagian penting yang harus dilakukan pelaku usaha. Sementara kepentingan keluarga sebagai akibat dari terpisahnya lokasi tinggal juga menyumbang peran signifikan bagi angka mobilitas manusia.

Manusia modern dewasa ini mempunyai kecenderungan semakin tinggi dalam perpindahan kedudukan atau dapat disebut dengan mobilitas. Perkembangan dunia kerja, informasi dan transportasi membuat mobilitas manusia modern semakin intens dan menjadi keniscayaan. Kemudahan transportasi menjadikan jarak antar lokasi tidak menghalangi mobilitas manusia modern. Dengan kemudahan dan kebutuhan mobilitas antar lokasi, dapat dikatakan bahwa keseharian manusia jaman sekarang tidak dapat menghindari untuk melakukan perjalanan antar daerah, bahkan antar negara.

Salah satu fasilitas penting yang dibutuhkan orang bepergian adalah akomodasi. Saat ini salah satu akomodasi yang paling diminati oleh wisatawan adalah hotel. Hotel adalah jenis akomodasi yang dikelola secara komersial dengan mempergunakan bangunannya baik hanya sebagian maupun secara keseluruhan untuk menyediakan jasa penginapan, makan, minum, hiburan serta jasa lainnya bagi 
kalangan umum. (Surachman, 1987). Industri hotel telah mengalami perkembangan sangat pesat. Para pengusaha hotel semakin terbuka dalam persaingan antar hotel. Terutama di kota-kota besar dan kota-kota yang memiliki potensi wisata tinggi dan mobilitas yang tinggi. Semakin meluasnya industri perhotelan yang modern, mengakibatkan terjadinya perubahan besar dalam kompleksitas permintaan konsumen. Perkembangan jumlah hotel di Indonesia yang semakin pesat memaksa pemilik ataupun pengelola perhotelan untuk melakukan langkah aktif dalam menjaring pelanggan. Kegiatan ini memerlukan aktivitas yang menggunakan strategi dan taktik yang direncanakan sedemikian rupa untuk menyampaikan cerita tentang pelayanan yang dapat diberikan suatu hotel sehingga mampu menarik pelanggan atau tamu hotel memilih suatu hotel. Kegiatan itulah yang disebut dengan pemasaran hotel yang salah satu instrumennya adalah promosi.

Kegiatan promosi suatu hotel menjadi sedemikian penting dalam pemasaran hotel selain instrumen produk dan distribusi. Tawaran kenyamanan dan layanan hotel harus menjadi fokus dalam usaha menarik pelanggan untuk menginap di suatu hotel. Melalui tiga instrumen pemasaran hotel yang terintegrasi itulah kelangsungan suatu hotel akan semakin berkembang.

$$
\text { Dengan adanya kemajuan }
$$

tekhnologi yang semakin pesat serta diiringi dengan kesibukan masingmasing individu yang mengharuskan mereka untuk mampu memanfaatkan kemajuan tekhnologi tersebut, salah satunya adalah internet. Menurut Lucas, (1993) yang mengadopsi pada Schroderbek, (1971) kemajuan teknologi informasi telah mampu menciptakan sebuah jaringan global yang disebut dengan internet. Awalnya pemanfaatan melalui media internet hanya digunakan untuk mendapatkan informasi. Informasi dapat diartikan sebagai sesuatu yang nyata yang dapat mengurangi derajat ketidakpastian tentang suatu keadaan atau kejadian. Internet menghilangkan semua batasbatas fisik yang memisahkan manusia dan menyatukannya dalam dunia baru, yaitu dunia maya. Internet juga telah mengubah wajah ekonomi konvensional yang lambat dan mengandalkan interaksi sumber daya fisik secara lokal menjadi ekonomi digital yang serba cepat dan mengandalkan interaksi sumber daya informasi secara global. Selain itu dengan adanya internet, produk maupun jasa apapun dapat dipasarkan melalui internet dan dapat berinteraksi jual beli melalui internet, yang lebih dikenal dengan Internet Marketing. Internet Marketing adalah usaha untuk memasarkan sesuatu (biasanya dalam bentuk produk/jasa) melalui media internet (Satriyo, 2011).

$$
\text { Sebenarnya antara Internet }
$$
Marketing dengan E-commerce hampir sama, hanya pada internet marketing lebih menekankan pada bidang pemasarannya daripada transaksi jual beli. Sama seperti pemasaran konvensional, aktifitas yang di lakukan pada internet marketing pada umumnya meliputi hal-hal yang berhubungan dengan pembuatan produk periklanan, pencarian prospek (calon pembeli/pelanggan), serta penulisan kalimat-kalimat pemasaran (copywriting). Adapun tehnik-tehnik yang umumnya di gunakan pada internet marketing meliputi pembuatan website/blog (Web development), promosi melalui banner di website milik orang lain (Banner/Link exchange), promosi melalui optimalisasi mesin pencari informasi (search engine 
optimization $\underline{S E O}$ ), promosi melalui $e$ mail (email advertising), pemasaran melalui sistem afiliasi (affiliate marketing), serta iklan interaktif (interactive advertising (Yurosie online news, 2011).

Dengan adanya Internet Marketing, maka perusahaan dapat memanfaatkan kecepatan dan ketepatan teknologi internet dalam menyampaikan informasi (Gm,Susanto, 2011). Apalagi dalam penjualan jasa seperti Hotel. Para pengunjung hotel tidak hanya melalui dalam negeri saja melainkan juga dari luar negeri sehingga pengunjung membutuhkan informasi yang cepat dan tepat serta tidak perlu untuk datang ke lokasi langsung.

Karena banyaknya hotel yang menawarkan fasilitas dan pelayanan penginapan (makan dan minum, jasajasa lainnya) membuat konsumen harus memikirkan dengan benar hotel mana yang akan menjadi tempat penginapan untuk sementara waktu. Hasil dari proses pemasaran yang diterima konsumen dan dianalisis menghasilkan suatu keputusan apakah akan menginap atau tidak di suatu hotel. Proses dalam pengambilan keputusan bukanlah proses sederhana,namun mempunyai beberapa faktor yang mempengaruhinya.

Berbicara tentang keputusan pembelian yang dilakukan konsumen, maka tidak akan terlepas dari faktorfaktor yang mempengaruhi konsumen dalam pengambilan keputusannya. Konsumen dalam pengambilan keputusannya dipengaruhi oleh kepentingan masing-masing yang timbul dari kekuatan rangsangan, yaitu personal characteristics (karakteristik individu), Lifestyle (gaya hidup), perception needs (kebutuhan persepsi), situations (situasi).

Menurut Shwu-Ing Wu, National Chin-Yi Institute of Technology bahwa personal characteristics (karakteristik individu) meliputi pendidikan, pekerjaan, penghasilan ; lifestyle (gaya hidup) meliputi fashion dan faktor ego, faktor kebebasan, faktor lingkungan keluarga, informasi yang didapat dan faktor kesukaan ; perception needs (kebutuhan persepsi) meliputi faktor keamanan dan kepercayaan, faktor pengetahuan dan pemahaman, faktor kenyamanan dan kecepatan, keefektifan; Situations (situasi) meliputi lokasi, frequensi pengunjung, penggunaan yang lebih banyak.

Dengan adanya Internet marketing ini, setiap keputusan pembelian, konsumen yang akan memesan hotel dapat memesan melalui media internet. Seorang tamu hotel sebelum mereka memilih hotel, pasti ada beberapa faktor yang dipertimbangkan. Misalnya pendapatan pengunjung, apakah cukup untuk memesan hotel tersebut ataukah tidak, situasi yang seperti apa yang diinginkan, lebih ke modern ataukah etnik, mencari informasi sebanyakbanyaknya tentang hotel yang akan dipesan (seperti fasilitas, bintang hotel, lokasi hotel) dan masih banyak lagi yang menjadi faktor keputusan konsumen dalam memilih hotel. Khususnya bagi tamu hotel dapat memanfaatkan kecanggihan tekhnologi, yaitu melalui Internet Marketing. Internet marketing adalah salah satu alat yang digunakan perusahaan dalam hal periklanan agar sampai keseluruh belahan dunia.

Hotel Candisari mempunyai letak yang strategis karena dekat berada di jalur utama Kebumen yang menghubungkan antar kota yang melalui jalur selatan yang cukup ramai dilalui kendaraan dari arah barat maupun dari arah timur. Lokasi kabupaten Kebumen yang berada di tengah dalam perjalanan antara Jakarta ke Jawa Timur atau sebaliknya, 
menjadikan lokasi Hotel Candisari yang berada di pinggir jalan jalur utama menjadi pilihan tepat untuk menjadi tempat menginap para pelancong yang kelelahan dalam perjalanan atau kemalaman untuk melanjutkan perjalanannya. Dengan kondisi semacam itu, maka segmen konsumen yang dituju lebih pada pelaku perjalanan yang berasal dari luar kota, bahkan terdapat konsumen yang berasal dari luar negeri. Hotel Candisari hotel kelas menengah yang memberikan kesempatan yang terbaik dalam business maupun pariwisata. Hotel Candisari memiliki 67 kamar yang sangat nyaman, serta makanan khas Indonesia yang disajikan di Coffee Shopnya. Selain itu, fasilitas yang ditawarkan Restaurant 24 jam non stop free hotspot, Gedung Pertemuan Outdoor dan Indoor, Karaoke, Wartel, Wedding Ceremony, dan Pompa Bensin - Letaknya yang sangat strategis menjadi salah satu andalan dari Hotel Candisari.

Hotel Candisari juga sudah menerapkan sistem internet marketing melalui web Hotel Candisari di www.candisarigroup.com . Selain itu, Hotel Candisari juga mempunyai Yahoo messanger, email, fax yang menjadi perantara internet marketing maupun penjualan kamar. Dengan adanya jaringan yang luas dan fasilitas yang mengagumkan membuat konsumen memilih untuk memikirkan apakah Hotel Candisari termasuk hotel yang mereka inginkan ataukah masih belum sesuai dengan selera konsumen.

\section{Rumusan Masalah}

1. Apakah terdapat pengaruh signifikan secara simultan Personal Characteristics, Lifestyle, Perception Needs, Situations terhadap tingkat keputusan konsumen dalam memilih hotel melalui internet marketing?

2. Apakah ada pengaruh secara signifikan parsial Personal Characteristics, Lifestyle, Perception Needs, Situations terhadap tingkat keputusan konsumen dalam memilih hotel melalui internet marketing?

3. Antara variabel Personal Characteristics, Lifestyle, Perception Needs, dan Situations, variabel manakah yang mempunyai pengaruh dominan terhadap tingkat keputusan konsumen dalam memilih hotel melalui internet marketing?

\section{Batasan Masalah}

1. Penelitian ini dibatasi pada faktorfaktor yang mempengaruhi keputusan konsumen dalam memilih hotel melalui internet marketing.

2. Adapun pengertian dari keputusan adalah pemilihan suatu tindakan dari dua atau lebih alternatif (Sciffman dan Kanuk dalam Sumarwan, 2004:289).

3. Konsumen yang dimaksud dalam penelitian ini adalah tamu yang menginap di Hotel Candisari.

4. Faktor-faktor yang mempengaruhi pengambilan keputusan konsumen adalah hal-hal terkait yang menjadi pertimbangan konsumen dalam menentukan keputusannya:

a. Gaya hidup adalah pola hidup seseorang di dunia yang diekspresikan dalam aktivitas, minat, dan opininya. Gaya hidup menggambarkan "keseluruhan diri seseorang" dalam berinteraksi dengan lingkungannya. Kotler (2002, p. 192)

b. Mathiue \& Zajac, (1990) menyatakan bahwa, 
Karakteristik personal (individu) mencakup usia, jenis kelamin, masa kerja, tingkat pendidikan, suku bangsa, dan kepribadian.

c. Persepsi adalah pengalaman tentang objek, peristiwa atau hubungan-hubungan yang diperoleh dengan mengumpulkan informasi dan menafsirkan peran (Rakhmat, 2005).

d. Situasi adalah keadaan yang terjadi baik itu jauh dari kita ataupun yang berada disekeliling kita.

\section{Tujuan Penelitian}

1. Untuk mengetahui pengaruh signifikan secara simultan Personal Characteristics, Lifestyle, Perception Needs, Situations terhadap tingkat keputusan konsumen dalam memilih hotel melalui internet marketing

2. Untuk mengetahui pengaruh signifikan secara parsial Personal Characteristics, Lifestyle, Perception Needs, Situations terhadap tingkat keputusan konsumen dalam memilih hotel melalui internet marketing.

3. Untuk mengetahui pengaruh Personal Characteristics, Lifestyle, Perception Needs, dan Situations, manakah yang mempunyai pengaruh dominan terhadap tingkat keputusan konsumen dalam memilih hotel melalui internet marketing.

\section{KAJIAN TEORI \\ Pengertian Hotel}

Menurut Dirjen Pariwisata, Hotel adalah suatu jenis akomodasi yang mempergunakan sebagian atau seluruh bangunan untuk menyediakan jasa penginapan, makan dan minum serta jasa lainnya bagi umum yang dikelola secara komersial.

Menurut Surat Keputusan Menteri Perhubungan R.I No. PM 10/PW301/Phb.77 tanggal 12 Desember 1977, Hotel adalah suatu bentuk akomodasi yang dikelola secara komersial, disediakan bagi setiap orang untuk memperoleh pelayanan penginapan berikut makan dan minum.

Menurut Hotel Proprietors Act (1956) dalam Dini (2005:) Hotel adalah suatu perusahaan yang dikelola oleh pemiliknya dengan menyediakan fasilitas kamar untuk tidur, pelayanan makanan dan minuman kepada orangorang yang sedang melakukan perjalanan dan mampu membayar dengan jumlah yang wajar sesuai dengan pelayanan yang diterima.

Dari keterangan beberapa pendapat, penulis menyimpulkan bahwa hotel adalah suatu perusahaan yang menyediakan pelayanan, akomodasi beserta makanan dan minuman untuk para pengunjung yang sedang melakuakan perjalanan dan membayar dengan jumlah yang wajar sesuai dengan pelayanan yang diterima.

\section{Karakteristik Hotel}

Hotel mempunyai karakteristik sebagai berikut :

a. Industri hotel tergolong industri padat modal serta padat karya yang artinya dalam pengelolaannya memerlukan modal usaha yang besar dengan tenaga kerja yang banya pula.

b. Dipengaruhi oleh keadaan dan perubahan yang terjadi pada sektor ekonomi, politik, sosial, budaya, dan keamanan dimana hotel tersebut berada.

c. Menghasilkan dan memasarkan produknya bersamaan dengan tempat dimana jasa terhadap pelayanan dihasilkan. 
d. Beroperasi 24 jam sehari, tanpa ada libur.

e. Melakukan pelanggan seperti raja, selain juga melakukan pelanggan sebagai partner dalam usaha karena jasa pelayanan hotel sangat tergantung pada banyaknya pelanggan yang menggunakan fasilitas hotel tersebut.

\section{Klasifikasi Hotel}

\section{a. Klasifikasi Hotel Berdasarkan Kamar :}

1) Single Room; kamar untuk satu orang yang dilengkapi dengan satu buah tempat tidur berukuran single (untuk satu orang)

2) Twin Room; kamar untuk dua orang yang dilengkapi dengan dua buah tempat tidur masingmasing berukuran single (untuk satu orang)

3) Double Room; kamar yang dilengkapi dengan satu buah tempat tidur berukuran double (untuk dua orang)

4) Double-Double; kamar untuk empat orang yang dilengkapi dengan dua kamar tamu dan dengan dua tempat tidur berukuran double (untuk dua orang).

b. Klasifikasi Hotel Berdasarkan Fasilitas Kamar :

1) Standart Room; kamar berukuran kecil dengan fasilitas tempat tidur, kamar mandi dan tv saja.

2) Superior Room; kamar berukuran sedang dengan fasilitas tempat tidur besar, kamar mandi, TV, dan pendingin ruangan.

3) Executive Room; kamar dengan ukuran besar, fasilitas tempat tidur besar, jendela yang menghadap ke pemandangan, kamar mandi, TV/DVD, pendingin ruangan.

4) Suite Room; kamar extra besar dengan balkon (teras), tempat tidur mewah, pemandangan indah, kamar mandi, TV/DVD, pendingin ruangan, dan serasa dirumah sendiri.

c. Klasifikasi Menurut Simbol Bintang :

Ada lima jenis simbol bintang pada hotel, yaitu mulai hotel berbintang satu sampai dengan hotel berbintang lima. Semakin tinggi bintang yang dimiliki hotel tersebut, semakin berkualitas hotel tersebut. Penilaian dilakukan selama tiga tahun sekali dengan tata cara dan penerapannya diputuskan oleh Direktorat Jendral Pariwisata.

d. Klasifikasi Berdasarkan Lokasi Hotel Dibangun :

1) City Hotel, hotel yang berlokasi di perkotaan, biasanya diperuntukkan bagi masyarakat yang bermaksud untuk tinggal sementara (dalam jangka waktu pendek). City Hotel disebut juga sebagai transit hotel karena biasanya dihuni oleh para pelaku bisnis yang memanfaatkan fasilitas dan pelayanan bisnis yang disediakan oleh hotel tersebut.

2) Residential Hotel, hotel yang berlokasi di daerah pingiran kota besar yang jauh dari keramaian kota, tetapi mudah mencapai tempat-tempat kegiatan usaha. Hotel ini berlokasi di daerahdaerah tenang, terutama karena diperuntukkan bagi masyarakat yang ingin tinggal dalam jangka waktu lama. Dengan sendirinya hotel ini diperlengkapi dengan fasilitas tempat tinggal yang lengkap untuk seluruh anggota keluarga. 
3) Resort Hotel, hotel yang berlokasi di daerah pengunungan (mountain hotel) atau di tepi pantai (beach hotel), di tepi danau atau di tepi aliran sungai. Hotel seperti ini terutama diperuntukkan bagi keluarga yang ingin beristirahat pada hari-hari libur atau bagi mereka yang ingin berekreasi.

4) Motel (Motor Hotel), hotel yang berlokasi di pinggiran atau di sepanjang jalan raya yang menghubungan satu kota dengan kota besar lainnya, atau di pinggiran jalan raya dekat dengan pintu gerbang atau batas kota besar. Hotel ini diperuntukkan sebagai tempat istirahat sementara bagi mereka yang melakukan perjalanan dengan menggunakan kendaraan umum atau mobil sendiri. Oleh karena itu hotel ini menyediakan fasilitas garasi untuk mob.

\section{Pengertian Internet Marketing}

Jika kita terjemahkan dalam bahasa Indonesia, internet marketing adalah pemasaran internet atau pemasaran melalui internet. Dan ini artinya masih membutuhkan strategi, karena didalam suatu pemasaran pasti terdapat strategi, apapun itu strateginya.

Menurut www.wikipedia.com, Internet Marketing adalah usaha untuk memasarkan sesuatu (biasanya dalam bentuk produk/jasa) melalui media internet.

Menurut Gm,Susanto, 2011, Internet Marketing adalah suatu sistem pemasaran yang memanfaatkan ketepatan dan kecepatan tekhnologi internet dalam menyampaikan informasi.

\section{Pemahaman Tentang Internet Marketing}

Sejak munculnya dunia kedua, yaitu dunia maya atau internet,bisa dikatakan definisi marketing mengalami sedikit perubahan atau pergeseran. Sedangkan dunia pertama yang pada beberapa tahun lalu banyak digunakan oleh perusahaan mengkomunikasikan sesuatu pesan secara massal melalui media tradisional (televisi, koran, radio, $\mathrm{dsb}$ ), tidak lagi begitu terlihat dampaknya, karena para konsumen sudah mulai bosan menghadapi caracara yang lama, dan mereka mulai melirik dunia kedua, yang pada saat ini mengalami peningkatan yang sangat drastis.

Jika sudah menyebut dunia kedua, maka sudah pasti cara pemasaran produk ataupun jasa, jauh berbeda dengan cara pemasaran di dunia maya, meskipun pada dasarnya kita masih harus melakukan observasi ataupun analisa, sebelum merancang sebuah strategi untuk internet marketing itu sendiri.

Banyak orang mengira internet marketing adalah SEO itu sendiri, sedangkan sebenarnya tidak. Jasa SEO hanya berlaku untuk search engine, sedangkan media di dunia kedua ada begitu banyak, dan sudah pasti mempunyai cara kerja yang berbeda. Kita juga harus mempelajari bagaimana cara memasarkan melalui social networks, apalagi sejak lahirnya social network terbaru, yaitu Google+, dan begitu juga dengan toko online, blog, website, forum, email, dll.

Dalam internet marketing kita harus beraktifitas, berproses didalam menciptakan, mengkomunikasikan dan menyampaikan sesuatu pesan kepada para penghuni dunia kedua, maka sudah pasti harus ditopang oleh perencanaan yang baik, strategi yang baik, serta visualisasi yang baik, baik secara grafis ataupun secara tekstual, demi mendapatkan enormous impact, 
melalui 'viral' itu sendiri.

\section{Macam-Macam Marketing dalam Bisnis Online}

a. Search engine marketing(SEM)

Pemasaran mesin pencari, adalah jenis upaya pemasaran yang dilakukan dengan menggunakan mesin pencari (search engine) sebagai medianya. Ini adalah tentang bagaimana mendapatkan posisi 10 besar mesin pencari atau setidaknya ada di halaman kedua serps dengan kata kunci niche kita. Berada di urutan halaman pertama hasil pencarian jelas akan kedatangan pengunjung yang datang melalui kata kunci yang berkaitan. Pengunjung yang datang ke website akan melihat isi website dan disinilah peran search engine marketing berada. Secara mendasar perannya hanya mendatangkan traffic. Traffic yang datang dari mesin pencari bukanlah sembarang traffic, karena kebanyakan atau setidanya lebih banyak adalah pengunjung yang ditarget sesuai kata kunci. Inilah sumber traffic dan pengunjung yang terbaik dalam bisnis online dan internet marketing. Namun ini juga yang terberat karena ini adalah berkaitan dengan SEO atau search engine optimization. Menguasai SEO atau setidaknya mengerti SEO adalah kebutuhan utama ketika ingin menggunakan marketing melalui search engine. Sekali lagi ini adalah tentang persaingan melawan ribuan atau bahkan jutaan situs pesaing bertema kata kunci sama.

b. E-mail marketing dan salesletter

Pemasaran melalui email dan surat penawaran atau salesletter. Jenis marketing yang sampai saat ini masih menjadi andalah para marketer kelas dunia dalam memasarkan produk produknya secara online di internet.. Cara kerjanya adalah mengirim email kepada seseorang atau beberapa orang secara masal yang berisi hal hal di atas dan pada akhirnya menuju ke satu arah yakni 'penjualan'. Email adalah media dan salesletter adalah isinya.

Cara mendapatkan alamat email yang benar ini lazimnya melalui form subsciber dan biasanya terhubung langsung dengan layanan 'autoresponder' (tidak gratis) yang akan menyimpan dan mengatur alamat email untuk dikirim email secara sah dan benar sehingga tidak dianggap spam.

c. PPC atau pay per click marketing

Ketika membicarakan traffic, maka jenis pengunjung atau traffic dari PPC disebut dengan istilah 'paid traffic' atau traffi yang bisa kita beli. Ingat ada dua macam traffic yakni, organic traffic dan paid traffic. PPC marketing ini adalah upaya pemasaran produk melalui iklan dengan membayar yang dihitung dari tiap klik pada publisher. Menurut banyak webmaster ini adalah cara termudah untuk mendapatkan traffic, bahkan pemula bisa mahir menggunakannya dan mendapatkan ribuah traffic dalam semalam saja. Join ke situs situs PPC, lakukan sign up, ikuti petunjuknya dan tunggu 1 jam kemudian traffic akan datang.

Google Adword( iklannya muncul di AdSense dan sebelah kanan halaman SERPs) dan Chitika Premium adalah contoh PPC terpopuler dan paling banyak digunakan oleh internet marketer dunia.

d. Video marketing 
Mendapatkan pengunjung dengan menggunakan video sebagai media marketing adalah salah satu yang terbaik saat ini. Membuat video dan unggah (upload) ke situs situs video sharing terkenal seperti Youtube dan lain sebagainya. Video yang diunggah adalah bersifat publik (Youtube) yang artinya siapa saja dapat mengaksesnya. Youtube ada author video dan fasilitas watermark yang bisa digunakan untuk menaruh link link

Hampir tidak ada persayaratan tertentu untuk mengunggah video seperti di Youtube. Video apa saja bisa disimpan disana dan siap disaksikan oleh pengguna internet di seluruh penjuru dunia.

e. Social media marketing

Pengguna sosial media seperti facebook dan twitter begitu banyak jauh diatas melampui media media lain di internet. Oleh karena itu pula sosial media khususnya facebook dan twitter menjadi media internet marketing yang paling baik.

Ada satu lagi pilihan lain yaitu dengan memasang iklan di facebook. Memasang iklan di facebook juga menggunakan sistem PPC atau pay per click. Cara ini juga dianggap cara paling mudah mendapatkan traffic. Cukup pasang iklan di facebook, dan lihatlah beberapa jam kemudian pengunjung berdatangan ke situs anda. Itulah social media marketing.

\section{Jenis-Jenis Internet Marketing}

a. Banner Advertisement (iklan melalui banner).

Jenis internet marketing ini ialah file grafis (biasanya berukuran 468 × 60 pixels atau $200 \times 200$ pixels atau bisa juga disesuaikan dengan keadaan yang ada) yang dipasangkan pada website penyedia iklan atau website orang lain. Iklan banner ini dimanfaatkan untuk mengarahkan pengunjung ke halaman website atau bloganda. Sebaiknya penyajian yang semenarik mungkin supaya calon pembeli membeli produk atau tertarik pada sesuatuyang ada pada website tersebut.

b. Sponsorship.

Jenis internet marketing ini adalah melakukan kegiatan tersebut untuk memikat calon pembeli,supaya benar-benar mau dan bersedia membeli produk yang dijual. Bisa dikatakan jika ada calon pembeli yang membeli atau menjualkan produk dari Anda maka Anda bisa memberikan bonus berupa link, uang, atau beberapa hal yang lain yang dirasa bermanfaat bagi pembeli yang membeli atau menjualkan produk dari Anda.

c. Classified Listings (daftar produk terklasifikasi).

Jenis internet marketing ini ialah seperti pada klasifikasi di surat kabar,koran, majalah. Klasifikasi online ialah cara yang sangat baik dan istimewa untuk memasang bisnis Anda yang ditujukan pada orang-orang yang siap untuk membeli produk Anda hasilkan. Kekuatan yang lebih hebat atau kelebihan atau bisa disebut keunggulan dari klasifikasi online dibandingkan dengan klasifikasi offline yaitu pengguna bisa mencari produk dengan cepat dan tepat dengan memanfaatkan form pencarian yang sudah terindeks dalam database. 
d. Email Marketing (pemanfaatan email).

Jenis internet marketing ini ialah pemasaran dengan memanfaatkan email pada penyebarannya. Email marketing bisa dilakukan dengan beberapa cara yaitu:

1) Dengan meletakkan iklan atau sebuah pesan di dalam email newsletter orang lain.

2) Dengan secara langsung mendistribusikan atau mengirimkan e-mail Anda kepada calon pelanggan atau calon pembeli yang berupa email penawaran biasa maupun dalam bentuk newsletter. Sebaiknya Anda memberikan informasi mengenai produk yang ditawarkan tanpa kesan paksaan. Hal itu dimaksudkan supaya calon konsumen dapat melakukan keputusan yang terbaik dalam menanggapi produk yang telah Anda tawarkan.

3) Anda bisa menyediakan fasilitas email subsriber pada website yang Anda miliki. Jika netter melakukan pendaftaran melalui e-mail subsriber yang ada pada website Anda, maka setiap kali Anda melakukan update pada website yang meliputi ( posting artikel atau produk ), maka email notifikasi bisa sampai kepada netter yang telah mendaftar secara otomatis dari setiap apa yang telah Anda update dari website Anda.

e. Partnership / Affiliate Marketing (pemasaran metode afiliasi).

Jenis internet marketing ini adalah dengan cara memanfaatkan para pengiklan. Para pengiklan yang menjual produknya dengan cara online bisa membangun jaringan afiliasi. Jaringan afiliasi adalah dengan melibatkan orang lain dalam penjualan produk yang ada. contohnya ialah http://www.amazon.com.

f. Search $\begin{gathered}\text { Engine Marketing } \\ \text { (pemasaran menggunakan mesin } \\ \text { pencari). }\end{gathered}$

Netter biasanya mencari informasi melalui search engine seperti Google dan Yahoo. Sebaian besar orang yang tidak tahu di mana harus mencari dan mendapatkan informasi yang mereka inginkan biasanya mereka mencarinya di situs mesin pencari itu (Google atau Yahoo). Maka jika perusahaan yang belum dikenalpublik atau bahkan sudah dikenal banyak orang, cara paling istimewa dan spektakuler yang sebaiknyadilakukan yaitu berusaha untuk mendapat tempat teratas pada mesin pencari (Google atau Yahoo). Setidaknya pada halaman pertama di mesin pencari. Suatu hal yang sangat penting untuk memastikan bahwa situs tersebut terdaftar dan terlampir dalam mesin pencari terkenal seperti google atau yahoo, apalagi pada halaman pertama . Banyak cara yang dapatdilakukan supaya website yangdimiliki terindeks pada mesin pencari tersebut (Google atau Yahoo) yang dikenal dengan Search Engine Optimization (SEO). g. Social Networking (metode pemasaran menggunakan situs jejaring sosial).

\begin{tabular}{llr}
\multicolumn{1}{c}{ Berbagai situs } & social \\
networking seperti Facebook, & Friendster, Twitter, MySpace, \\
Linkedln, dan MeetUp bisa \\
digunakan sebagai senjata e- \\
marketing yang ampuh dan \\
dahsyat. Facebook dan Friendster
\end{tabular}


menyediakan fasilitas embed audio dan video. Selain itu beberapa situs sosial network yang mengijinkan menyertakan audio atau video klip ialah www.Vsocial.com, www.MySpace.com, www.YouTube.com, dan www.Grouper.com.Memanfaatkan situs jejaring sosial merupakan cara efektif untuk mendemonstrasikan atau menunjukkan kemampuan pengetahuan dan komunikasi kita untuk mendapatkan calon pembeli.

\section{Gaya Hidup}

\section{Pengertian Gaya Hidup}

Gaya hidup adalah pola hidup seseorang di dunia yang diekspresikan dalam aktivitas, minat, dan opininya. Gaya hidup menggambarkan "keseluruhan diri seseorang" dalam berinteraksi dengan lingkungannya. Kotler (2002, p. 192)

Gaya hidup menggambarkan seluruh pola seseorang dalam beraksi dan berinteraksi di dunia. Menurut Assael (1984, p. 252), gaya hidup adalah " $A$ mode of living that is identified by how people spend their time (activities), what they consider important in their environment (interest), and what they think of themselves and the world around them (opinions)".

Secara umum dapat diartikan sebagai suatu gaya hidup yang dikenali dengan bagaimana orang menghabiskan waktunya (aktivitas), apa yang penting orang pertimbangkan pada lingkungan (minat), dan apa yang orang pikirkan tentang diri sendiri dan dunia di sekitar (opini). Sedangkan menurut Minor dan Mowen (2002, p. 282), gaya hidup adalah menunjukkan bagaimana orang hidup, bagaimana membelanjakan uangnya, dan bagaimana mengalokasikan waktu. Selain itu, gaya hidup menurut Suratno dan Rismiati (2001, p. 174) adalah pola hidup seseorang dalam dunia kehidupan sehari-hari yang dinyatakan dalam kegiatan, minat dan pendapat yang bersangkutan. Gaya hidup mencerminkan keseluruhan pribadi yang berinteraksi dengan lingkungan.

Dari berbagai di atas dapat disimpulkan bahwa gaya hidup adalah pola hidup seseorang yang dinyatakan dalam kegiatan, minat dan pendapatnya dalam membelanjakan uangnya dan bagaimana mengalokasikan waktu. Faktor-faktor utama pembentuk gaya hidup dapat dibagi menjadi dua yaitu secara demografis dan psikografis. Faktor demografis misalnya berdasarkan tingkat pendidikan, usia, tingkat penghasilan dan jenis kelamin, sedangkan faktor psikografis lebih kompleks karena indikator penyusunnya dari karakteristik konsumen.

\section{Gaya Hidup AIO (Activity,} Interest, Opinion)

Psikografik

(Psychographic) adalah ilmu tentang pengukuran dan pengelompokkan gaya hidup konsumen (Kotler, 2002, p. 193). Sedangkan psikografik menurut Sumarwan (2003, p. 58), adalah suatu instrumen untuk mengukur gaya hidup, yang memberikan pengukuran kuantitatif dan bisa dipakai untuk menganalisis data yang sangat besar. Analisis psikografik biasanya dipakai untuk melihat segmen pasar. Analisis psikografik sering juga diartikan sebagai suatu riset konsumen yang menggambarkan segmen konsumen dalam hal kehidupan, pekerjaan dan 
aktivitas lainnya. Psikografik berarti menggambarkan (graph) psikologis konsumen ( $p s y c o$ ).

Psikografik adalah pengukuran kuantitatifgaya hidup, kepribadian dan demografik konsumen. Psikografik sering diartikansebagai pengukuran AIO (activity, interest, opinions), yaitu pengukuran kegiatan, minat dan pendapat konsumen. Psikografik memuat beberapa pernyataan yang menggambarkan kegiatan, minat dan pendapat konsumen. Pendekatan psikografik sering dipakai produsen dalam mempromosikan produknya, seperti yang dinyatakan oleh Kotler bahwa psikografik senantiasa menjadi metodologi yang valid dan bernilai bagi banyak pemasar (2002, p. 193). Solomon dalam Sumarwan (2003, p. 59) menjelaskan studi psikografik dalam beberapa bentuk seperti diuraikan berikut.

a. Profil gaya hidup (a lifestyle profile), yang menganalisis beberapa karakteristik yang membedakan antara pemakai dan bukan pemakai suatu produk.

b. Profil produk spesifik ( $a$ product-specific profile) yang mengidentifikasi kelompok sasaran kemudian membuat profil konsumen tersebut berdasarkan dimensi produk yang relevan.

c. Studi yang menggunakan kepribadian ciri sebagai faktor yang menjelaskan, menganalisis kaitan beberapa variabel dengan kepribadian ciri, misalnya kepribadian ciri yang mana yang sangat terkait dengan konsumen yang sangat memperhatikan masalah lingkungan. d. Segmentasi gaya hidup (a general lifestyle segmentation), membuat pengelompokkan responden berdasarkan kesamaan preferensinya.

e. Segmentasi produk spesifik, adalah studi yang mengelompokkan konsumen berdasarkan kesamaan produk yang dikonsumsinya.

Orang-orang yang berasal dari sub-budaya, kelas sosial, dan pekerjaan yang sama dapat memiliki gaya hidup yang berbeda. Gaya hidup adalah pola hidup seseorang di dunia yang diekspresikan dalam aktivitas, minat, dan opininya. Gaya hidup menggambarkan "keseluruhan diri seseorang" yang berinteraksi dengan lingkungannya. Pemasar mencari hubungan antara produknya dengan kelompok gaya hidup konsumen. Contohnya, perusahaan penghasil komputer mungkin menemukan bahwa sebagian besar pembeli komputer berorientasi pada pencapaian prestasi. Dengan demikian, pemasar dapat dengan lebih jelas mengarahkan mereknya ke gaya hidup orang yang berprestasi.

\section{Karakteristik Individu}

1. Pengertian Karakteristik Individu Sumber daya yang terpenting dalam organisasi adalah sumber daya manusia, orang-orang yang memberikan tenaga, bakat, kreativitas, dan usaha mereka kepada organisasi agar suatu organisasi dapat tetap eksistensinya. Setiap manusia memiliki karakteristik individu yang berbeda antara satu dengan yang lainnya. Berikut ini beberapa pendapat mengenai karakteristik individu. 
Mathiue \& Zajac, (1990) menyatakan bahwa, Karakteristik personal (individu) mencakup usia, jenis kelamin, masa kerja, tingkat pendidikan, suku bangsa, dan kepribadian. Robbins (2006) menyatakan bahwa, Faktor-faktor yang mudah didefinisikan dan tersedia, data yang dapat diperoleh sebagian besar dari informasi yang tersedia dalam berkas personalia seorang pegawai mengemukakan karakteristik individu meliputi usia, jenis kelamin, status perkawinan, banyaknya tanggungan dan masa kerja dalam organisasi.

Siagian (2008) menyatakan bahwa, Karakteristik biografikal (individu) dapat dilihat dari umur, jenis kelamin, status perkawinan, jumlah tanggungan dan masa kerja. Menurut Morrow menyatakan bahwa, komitmen organisasi dipengaruhi oleh karakter personal (individu) yang mencakup usia, masa kerja, pendidikan dan jenis kelamin (Prayitno, 2005). Dari pendapat Robbins dan Siagian di atas yang membentuk karakteristik individu dalam organisasi meliputi: usia, jenis kelamin, status perkawinan, masa kerja, dan jumlah tanggungan.

2. Faktor-faktor Karakteristik Individu Ada beberapa faktor dari karakteristik individu, antara lain:

a. Usia

Usia (umur) adalah lama waktu hidup atau ada (sejak dilahirkan atau diadakan). Dyne dan Graham (2005) menyatakan bahwa,Pegawai yang berusia lebih tua cenderung lebih mempunyai rasa keterikatan atau komitmen pada organisasi dibandingkan dengan yang berusia muda sehingga meningkatkan loyalitas mereka pada organisasi. Hal ini bukan saja disebabkan karena lebih lama tinggal di organisasi, tetapi dengan usia tuanya tersebut, makin sedikit kesempatan pegawai untuk menemukan organisasi.

Robbins (2003) menyatakan bahwa, Semakin tua usia pegawai, makin tinggi komitmennya terhadap organisasi, hal ini disebabkan karena kesempatan individu untuk mendapatkan pekerjaan lain menjadi lebih terbatas sejalan dengan meningkatnya usia. Keterbatasan tersebut dipihak lain dapat meningkatkan persepsi yang lebih positif mengenai atasan sehingga dapat meningkatkan komitmen mereka terhadap organisasi.

Nitisemito

menyatakan bahwa, Pegawai yang lebih muda cenderung mempunyai fisik yang kuat, sehingga diharapkan dapat bekerja keras dan pada umumnya mereka belum berkeluarga atau bila sudah berkeluarga anaknya relatif masih sedikit. Tetapi pegawai yang lebih muda umumnya kurang berdisiplin, kurang bertanggungjawab dan sering berpindah-pindah pekerjaan dibandingkan pegawai yang lebih tua.

b. Jenis Kelamin

Sebagai makhluk Tuhan Yang Maha Esa, manusia dibedakan menurut jenis kelaminnya yaitu pria dan wanita. Robbins (2003) menyatakan bahwa, Tidak ada perbedaan yang konsisten antara pria dan wanita dalam kemampuan memecahkan 
masalah, ketrampilan analisis, dorongan kompetitif, motivasi, sosiabilitas atau kemampuan belajar. Namun studi-studi psikologi telah menemukan bahwa wanita lebih bersedia untuk mematuhi wewenang dan pria lebih agresif dan lebih besar kemungkinannya daripada wanita dalam memiliki pengharapan untuk sukses. Bukti yang konsisten juga menyatakan bahwa wanita mempunyai tingkat kemangkiran yang lebih tinggi dari pada pria. Dyne dan Graham (2005) menyatakan bahwa Pada umumnya wanita menghadapi tantangan lebih besar dalam mencapai karirnya, sehingga komitmennya lebih tinggi. Hal ini disebabkan pegawai wanita merasa bahwa tanggung jawab rumah tangganya ada di tangan suami mereka, sehingga gaji atau upah yang diberikan oleh organisasi bukanlah sesuatu yang sangat penting bagi dirinya.

Mowday

menyatakan bahwa, Wanita sebagai kelompok cenderung memiliki komitmen terhadap organisasi lebih tinggi dibandingkan dengan pria. Wanita pada umumnya harus mengatasi lebih banyak rintangan dalam mencapai posisi mereka dalam organisasi sehingga keanggotaan dalam organisasi menjadi lebih penting bagi mereka.

c. Status Perkawinan

Status perkawinan adalah ikatan lahir batin antara pria dan seorang wanita sebagai suami istri dengan tujuan membentuk keluarga yang bahagia dan kekal berdasarkan Ketuhanan Yang
Maha Esa. Soekanto (2000), menyatakan bahwa, Perkawinan (marriage) adalah ikatan yang sah antara seorang pria dan wanita yang menimbulkan hakhak dan kewajiban-kewajiban antara mereka maupun turunannya. Robbins (2003) menyatakan bahwa, Pernikahan memaksakan peningkatan tanggung jawab yang dapat membuat suatu pekerjaan yang tetap menjadi lebih berharga dan penting.

d. Masa Kerja

Menurut Balai Pustaka Departemen Pendidikan dan Kebudayaan (1991) menyatakan bahwa, Masa kerja (lama bekerja) merupakan pengalaman individu yang akan menentukan pertumbuhan dalam pekerjaan dan jabatan. Menurut kamus besar bahasa Indonesia (1984), Pengalaman kerja didefinisikan sebagai suatu kegiatan atau proses yang pernah dialami oleh seseorang ketika mencari nafkah untuk memenuhi kebutuhan hidupnya. Siagian (2008) menyatakan bahwa, Masa kerja menunjukkan berapa lama seseorang bekerja pada masingmasing pekerjaan atau jabatan. Kreitner dan Kinicki (2004) menyatakan bahwa, Masa kerja yang lama akan cenderung membuat seorang pegawai lebih merasa betah dalam suatu organisasi, hal ini disebabkan diantaranya karena telah beradaptasi dengan lingkungannya yang cukup lama sehingga seorang pegawai akan merasa nyaman dengan pekerjaannya. Penyebab lain juga dikarenakan adanya kebijakan dari instansi atau 
perusahaan mengenai jaminan hidup di hari tua.

e. Jumlah Tanggungan

Siagian (2008) menyatakan bahwa, Jumlah tanggungan adalah seluruh jumlah anggota keluarga yang menjadi tanggungan seseorang. Berkaitan dengan tingkat absensi, jumlah tanggungan yang lebih besar akan mempunyai kecenderungan absen yang kecil, sedangkan dalam kaitannya dengan turn over maka semakin banyak jumlah tanggungan seseorang, kecenderungan untuk pindah pekerjaan semakin kecil.

\section{Persepsi}

1. Pengertian Persepsi

Persepsi adalah pengalaman tentang objek, peristiwa atau hubungan-hubungan yang diperoleh dengan mengumpulkan informasi dan menafsirkan peran (Rakhmat, 2005). Persepsi itu bersifat individual, karena persepsi merupakan aktivitas yang terintegrasi dalam individu, maka persepsi dapat dikemukakan karena perasaan dan kemampuan berfikir. Pengalaman individu tidak sama, maka dalam mempersepsikan stimulus, hasil dari persepsi mungkin dapat berbeda satu dengan yang lain karena sifatnya yang sangat subjektif (Roger 1965 dalam Walgito, 2002).

2. Faktor Yang Mempengaruhi Persepsi

Menurut Siagian (1995) ada
beberapa
mempengaruhi

a. Diri orang yang bersangkutan, dalam hal ini orang yang berpengaruh adalah karakteristik individual meliputi dimana sikap, kepentingan, minat, pengalaman dan harapan.

b. Sasaran persepsi, yang menjadi sasaran persepsi dapat berupa orang, benda, peristiwa yang sifat sasaran dari persepsi dapat mempengaruhi persepsi orang yang melihatnya. Hal-hal lain yang ikut mempengaruhi persepsi seseorang adalah gerakan, suara, ukuran, tindak tanduk dan lain-lain dari sasaran persepsi.

c. Faktor situasi, dalam hal ini tinjauan terhadap persepsi harus secara kontekstual artinya perlu dalam situasi yang mana persepsi itu timbul. Sementara menurut Walgito (2002) dalam persepsi individu mengorganisasikan dan menginterpretasikan stimulus mempunyai arti individu yang bersangkutan dimana stimulus merupakan salah satu faktor yang berperan dalam persepsi.

\section{Situasi}

1. Pengertian situasi

Faktor situasional adalah kondisi sesaat yang muncul pada tempat dan waktu tertentu Kemunculanya terpisah dari diri produk maupun konsumen ( Asseal , 1998) dalam Virgi Kastama Soar. Sedangkan menurut Belik ( 1975 ) dalam Virgi Kastama Soar , mendifinisikan situasi sebagai semua faktor yang utama terhadap tempat dan situasi yang tidak menurut pengetahuan seseorang ( intra individu ) dan stimulasi ( alternative pilihan ) dan memiliki bukti dan pengaruh sistimatis pada prilaku saat itu .

Lain halnya dengan wilkie ( 1990 ) dalam Virgi Kastama Soar . pengaruh situasional adalah kekuatan sesaat yg tidak berasal 
dari dalam diri seseorang atau berasal dari produk atau merek yang di pasarkan, penelitian telah menemukan bahwa faktor situasional mempengaruhi pilihan konsumen dengan mengubah kemungkinan pemilihan berbagai alternative ( kolm,Monroe,dan Glazer, 1987, dalam titus dan Ernett, 1996 ) .

2. Faktor- Faktor Situasi Konsumen

Pengaruh situasional dalam konsumen adalah faktor personal dan lingkungan sementara yang muncul pada saat aktifitas konsumen , sehingga situasi konsumen meliputi faktor-faktor seperti :
1) Melibatkan waktu dan tempat
dalam mana aktifitas konsumen terjadi ,
2) Mempengaruhi tindakan konsumen sperti prilaku pembelian, dan
3) Tidak termasuk karakteristik personal yang berlaku dalam jangka panjang .
Situasi konsumen relatif

merupakan kejadian jangka pendek dan harus dibedakan dengan lingkungan makro atau faktorfaktor personal yang memiliki jangka waktu lama .

3. Jenis-Jenis Situasi

Menurut Asseal ( 1998 ), terdapat tiga jenis situasi berkaitan dengan pemasaran yaitu : situasi konsumsi situasi pembelian, dan situasi komunikasi.

4. Interaksi Orang Dengan Situasi

Memahami serta menganalisis pengaruh situasi dalam proses pembelian barang, banyak dan konsumen yang di pengaruhi oleh variasi dari situasi lain yang sesuai dengan keadaan mereka saat itu.

5. Pengaruh Situasi Yang Tak Terduga

Bagaimana seseorang mengerti akan potensi dari pengaruh situasi yang tak terduga yang dapat merusak keakuratan ramalan yang didasarkan pada maksud pembelian , yang tadinya dia tidak mau embeli barang tapi karena suatu hal jadi membeli barang tersebut. 


\section{Kerangka Pemikiran}

\section{Model Kerangka Pikir}

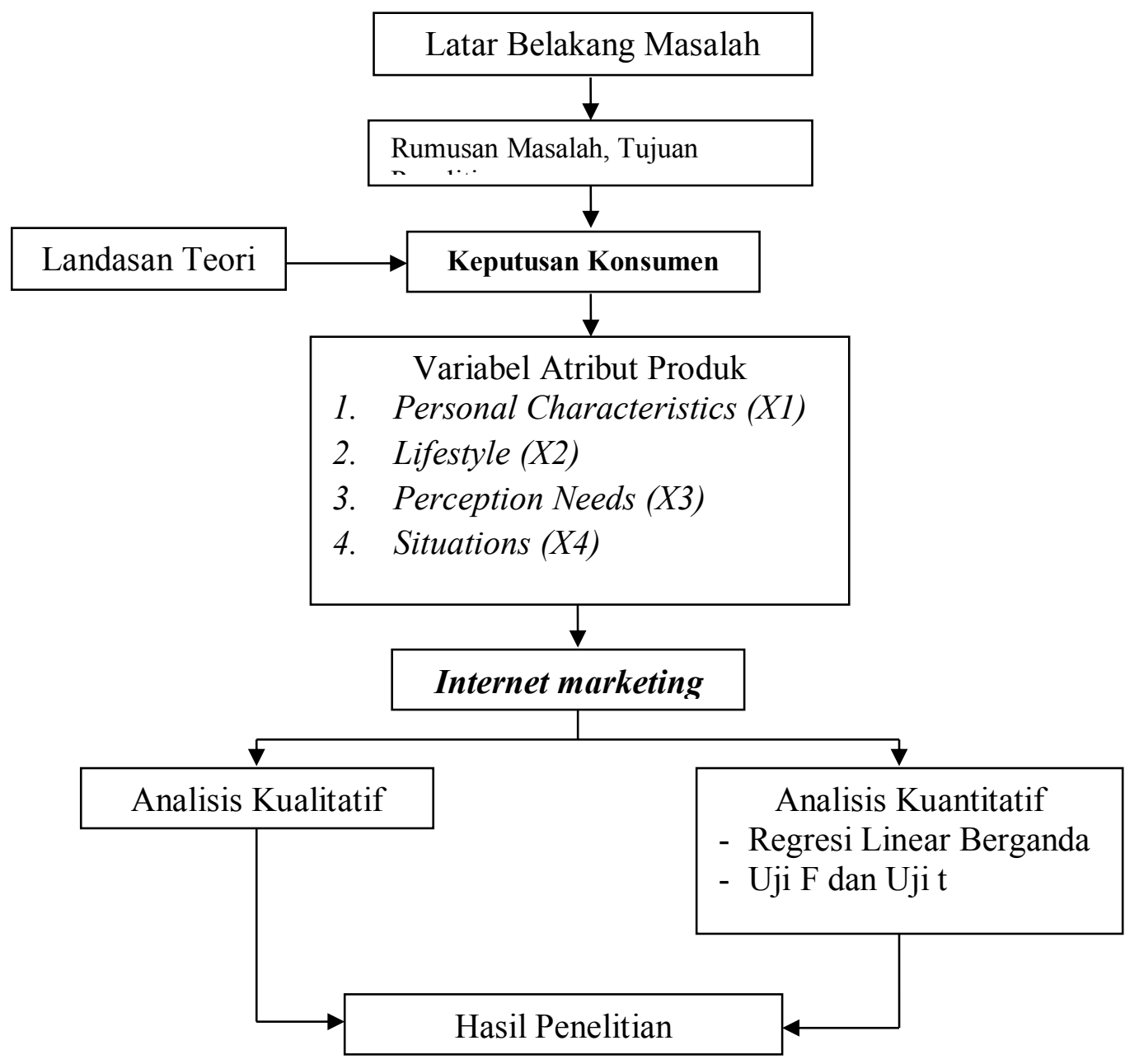




\section{Hipotesis}

Arikunto (2002:67) hipotesis adalah suatu jawaban sementara terhadap permasalahan penelitian sampai terbukti melalui data yang terkumpul.

\section{Model Kerangka Hipotesis}

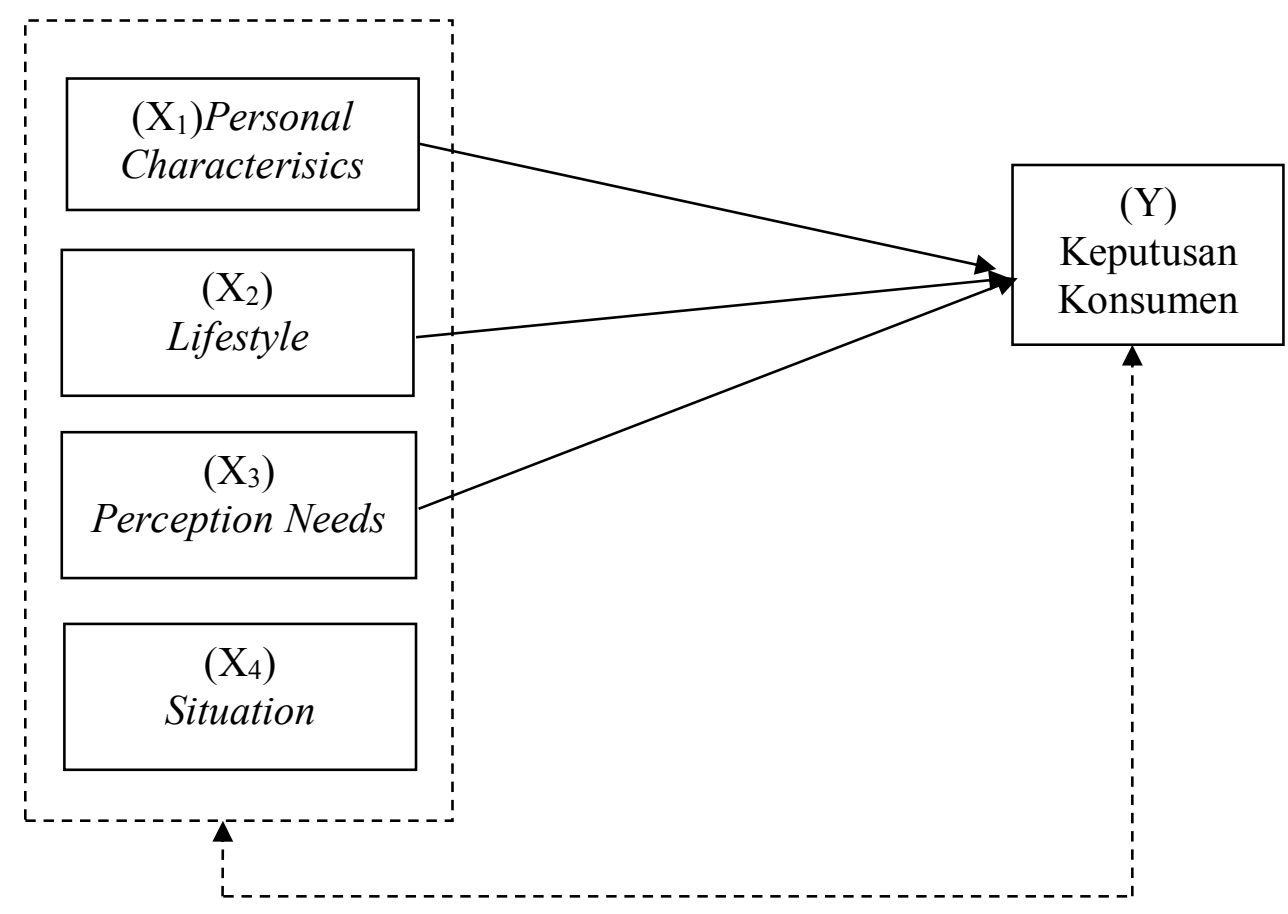

Keterangan :

$\mathrm{X}=$ Variabel Bebas

$\mathrm{Y}=$ Variabel Terikat (Keputusan Konsumen)

$\longrightarrow=$ Pengaruh Secara Parsial

= Pengaruh Secara Simultan

Berdasarkan kerangka pikir di atas dapat dirumuskan hipotesis penelitian sebagai berikut:

H1 : Ada pengaruh signifikan secara Parsial Personal Characteristics, Lifestyle, Perception Needs, Situations terhadap keputusan konsumen dalam memilih hotel melalui internet marketing

H2 : Ada pengaruh signifikan secara simultan Personal Characteristics, Lifestyle, Perception Needs, Situations terhadap keputusan konsumen dalam memilih hotel melalui internet marketing

H3 : Variabel Situations berpengaruh dominan terhadap terhadap tingkat keputusan konsumen dalam memilih hotel melalui internet marketing 


\section{METODE PENELITIAN}

Obyek dan Subyek Penelitian

Obyek dalam penelitian ini adalah personal characteristics (karakteristik individu), Lifestyle (gaya hidup), perception needs (kebutuhan persepsi), situations (situasi). Adapun yang menjadi subyek dalam penelitian adalah tamu yang pernah menginap di Hotel Candisari Karanganyar - Kebumen.

\section{Variabel Penelitian dan Definisi Operasional Variabel Variabel Penelitian}

Dalam penelitian ini terdapat lima variabel penelitian yang terdiri dari dua unsur, yaitu variabel independen atau variabel bebas dan variabel dependen atau variabel terikat. Variabel dependen dalam penelitian ini adalah variabel keputusan konsumen, sedangkan variabel independen dalam penelitian ini adalah variabel karakteristik individu (Personal Characteristic), gaya hidup (Lifestyle), kebutuhan persepsi (Perception Needs), dan situasi (Situations).

\section{Definisi Operasional Variabel}

Definisi operasional merupakan semacam petunjuk pelaksanaan bagaimana caranya mengukur suatu variabel sehingga dapat menentukan apakah prosedur pengukuran yang sama akan dilakukan atau diperlukan prosedur pengukuran yang baru. Variabel dalam penelitian ini menurut Shwu-Ing Wu, National Chin-Yi Institute of Technology dapat diuraikan sebagai berikut:

1. Variabel Bebas " $X$ "

(Independent Variabel)

\section{a. Personal Characteristics /} Karakteristik Individu (X1)

Karakteristik Individu (X1) adalahSumber daya yang terpenting dalam organisasi adalah sumber daya manusia, orang-orang yang memberikan tenaga, bakat, kreativitas, dan usaha mereka kepada organisasi agar suatu organisasi dapat tetap eksistensinya. Setiap manusia memiliki karakteristik individu yang berbeda antara satu dengan yang lainnya.

b. Lifestyle / Gaya Hidup (X2)

Gaya hidup adalah pola hidup seseorang di dunia yang diekspresikan dalam aktivitas, minat, dan opininya. Gaya hidup menggambarkan "keseluruhan diri seseorang" dalam berinteraksi dengan lingkungannya.

(X3)

c. Perception Needs / Persepsi

Persepsi adalah pengalaman tentang objek, peristiwa atau hubungan-hubungan yang diperoleh dengan mengumpulkan informasi dan menafsirkan peran.

\section{d. Situations / Situasi (X4)}

Situasi adalah keadaan yang terjadi baik itu jauh dari kita ataupu yang berada disekeliling kita. Item variabel ini adalah

2. Variabel terikat " $Y$ " (dependent variable)

Variabel terikat dalam penelitian ini adalah Keputusan Konsumen (Y) pada Hotel Candisari,Karanganyar.

\section{Instrumen atau Alat Pengumpulan Data}

Menurut Sugiyono (2009:92) skala pengukuran merupakan kesepakatan yang digunakan sebagai acuan untuk menentukan panjang pendeknya interval yang ada dalam alat ukur, sehingga alat ukur tersebut apabila digunakan dalam pengukuran akan menghasilkan data kuantitatif. Dalam penelitian ini menggunakan skala Likert, yaitu dengan memberikan pilihan jawaban untuk rata- 
rata pernyataan.

Penentuan skor pada instrument penelitian ini adalah sebagai berikut :

Sangat Setuju diberi

skor : 4

Setuju

diberi

skor : 3

Tidak Setuju diberi

skor : 2

Sangat Tidak Setuju diberi

skor : 1

\section{Data}

Jenis data dalam penelitian ini digolongkan menjadi data primer dan data sekunder. Menurut Marzuki (2005:59) data dapat dibedakan berdasarkan sumbernya, yaitu :

1. Data Primer

Dalam hal penelitian ini data primer diperoleh dari jawaban kuesioner yang telah diisi oleh responden atau tamu yang pernah bermalam di Hotel Candisari,Karanganyar.

2. Data Sekunder

Dalam penelitian ini, menggunakan data sekunder internal yang berasal dari Hotel Candisari,Karanganyar, yaitu berupa sejarah Hotel Candisari,Karanganyar dan struktur organisasi. Data sekunder eksternal merupakan data yang dikumpulkan di luar organisasi. Data sekunder ini diperoleh dari literatur, yaitu berupa kajian teori, penelitian terdahulu.

\section{Alat Pengumpulan Data}

Teknik pengumpulan data yang digunakan dalam penelitian ini adalah :

1. Wawancara

Pada penelitian ini wawancara dilakukan oleh pihak-pihak terkait pada penelitian untuk mendapatkan data yang menunjang, yaitu tamu yang pernah bermalam di Hotel Candisari,Karanganyar, serta pihak- pihak yang terkait dengan perusahaan tersebut.

2. Kuesioner (angket)

Penelitian ini menggunakan dua tipe kuesioner (angket) yaitu :

a. Kuesioner terbuka, yaitu memberikan kesempatan pada responden untuk menjawab dengan kalimatnya sendiri. Pada penelitian ini terdiri dari pertanyaan mengenai nama, jenis kelamin, usia, pendidikan, pekerjaan.

b. Kuesioner tertutup, yaitu responden tinggal memilih jawaban yang telah disediakan. Pada penelitian ini meliputi pertanyaan-pertanyaan yang terdapat pada kuesioner penelitian, dalam penelitian ini kuesioner diberikan kepada responden yaitu tamu yang pernah bermalam di Hotel Candisari Karanganyar.

3. Dokumentasi

Teknik ini dilakukan dengan mengadakan pencatatan terhadap dokumen-dokumen sejarah singkat perusahaan, struktur organisasi, visi dan misi, fasilitas hotel dan hal-hal lain yang menunjang penelitian.

4. Studi Pustaka

Mempelajari literatur atau bukubuku yang relevan, surat kabar, jurnal, artikel, maupun penelitian atau tulisan ilmiah yang berkaitan.

\section{Populasi dan Sampel \\ Populasi}

Menurut Arikunto (2002:18) populasi merupakan keseluruhan subjek penelitian. Sekaran (2006:121) mengemukakan bahwa populasi (population) mengacu pada keseluruhan kelompok orang, kejadian, atau hal minat yang ingin peneliti investigasi. Berdasarkan pengertian di atas, maka populasi pada penelitian ini adalah 
seluruh tamu yang pernah bermalam di Hotel Candisari.

\section{Sampel}

Untuk menentukan ukuran sampel, peneliti berpedoman pada pendapat yang dikemukakan oleh Roscoe dalam Sekaran (2006:160) yang mengusulkan aturan sampel lebih dari 30 dan kurang dari 500 adalah tepat untuk kebanyakan penelitian multivariate (termasuk analisis regresi berganda), ukuran sampel sebaiknya beberapa kali (lebih disukai 10 kali atau lebih) lebih besar dari jumlah variabel dalam studi. Adapun jumlah sampel yang diambil dalam penelitian ini yaitu sebesar 100 responden, yang menjadi landasan atau dasar dari jumlah pengambilan sampel adalah pandangan Fraenkel dan Wallen dalam Widayat (2002:67) mengatakan bahwa: "Besarnya sampel minimum untuk penelitian yang bersifat deskriptif yaitu sebanyak 100 sampel."

\section{Teknik Pengambilan Sampel}

Teknik pengambilan sampel yang digunakan adalah non-probability sampling-Insidental sampling. Menurut Sugiyono (2009:85) Metode pengambilan sampel yang digunakan adalah accidental sampling yaitu tehnik penetuan sampel berdasarkan kebetulan, yaitu siapa saja yang kebetulan bertemu dengan peneliti dapat digunakan sebagai

\section{Uji Validitas}

Untuk menguji validitas menggunakan Person Correlation yaitu sebagai berikut:

$$
r=\frac{n \sum x y-\left(\sum x\right)\left(\sum y\right)}{\sqrt{\left\{n \sum x^{2}-\left(\sum x\right)^{2}\right\}\left\{n x y^{2}-\left(\sum y\right)^{2}\right\}}}
$$

Keterangan :

$\mathrm{r}$ : koefisien korelasi

$\mathrm{n}$ : banyak sampel

$\mathrm{X}$ : nilai ítem pertanyaan

$\mathrm{Y}$ : nilai total item sampel bila dipandang orang tersebut sesuai dengan sumber data.

\section{Teknik Analisis Data \\ Analisis Deskriptif}

Analisis deskriptif atau kualitatif digunakan untuk menganalisis data yang bersifat deskriptif dari hasil jawaban kuisioner, misalnya jumlah responden, usia, jenis kelamin, status perkawinan, pekerjaan, pendapatan, dan lain-lain untuk dicari relevansinya dengan teori. Analisis deskriptif dimaksudkan untuk mendeskripsikan atau memberi gambaran terhadap obyek yang diteliti melalui data atau populasi sebagaimana adanya tanpa melakukan analisis dan membuat kesimpulan yang berlaku secara umum. Adapun data yang diperoleh melalui analisis deskriptif ini dilakukan dengan caracara penyajiannya dalam bentuk tabel biasa maupun distribusi frekuensi.

\section{Analisis Statistik}

Analisis statistik atau kuantitatif digunakan untuk menganalisis data dari hasil jawaban kuisionerdengan menggunakan metode-metode statistik. Penelitian ini menggunakan pengujian validitas dan reliabilitas dengan program SPSS 22 (Statistical Product and Services Solutions)

Tingkat validitas diperoleh dengan membandingkan probabilitas nilai $r$ dengan alpha-nya. Bila probabilitas $\leq$ 0,05 maka alat ukur tersebut dikatakan valid.

\section{Uji Reliabilitas}

Dalam penelitian ini pengujian reliabilitas menggunakan rumus Alpha. Menurut Arikunto (2002:171) rumus alpha digunakan untuk mencari reliabilitas instrumen yang skornya bukan 1 dan 0 , misal angket atau soal bentuk uraian.

Dengan rumus sebagai berikut: 
$r_{11}=\left(\frac{k}{(k-1)}\right)\left(1-\frac{\sum \sigma_{b}{ }^{2}}{\sigma_{1}{ }^{2}}\right)$

Keterangan :

$\mathrm{r}_{11}=$ Reliabilitas instrument

$\mathrm{k}=$ Banyaknya butir

pertanyaan atau banyaknya soal

$\begin{array}{ll}\sum \alpha_{b}{ }^{2} & =\text { Jumlah varian butir } \\ \alpha_{1}{ }^{2} & =\text { Varian total }\end{array}$

Suatu instrument dapat dikatakan reliabel jika memiliki nilai koefisien keandalan lebih besar atau sama dengan 0,6 . sehingga apabila $\alpha$ sama dengan 0,6 maka instrument dapat dikatakan reliabel.

\section{Uji Asumsi Klasik}

a. Uji Multikolinieritas

Multikolinieritas berarti adanya hubungan yang sempurna atau pasti diantara beberapa atau semua variabel yang menjelaskan garis regresi (Gujarati 1997:45). Model regresi yang baik seharusnya tidak terjadi korelasi diantara variabel independent. Cara mendeteksi ada tidaknya gejala multikolinieritas adalah dengan melihat nilai Variance Inflation Factor (VIF) atau faktor pertambahan ragam. Apabila nilai VIF lebih besar dari 10 maka terjadi multikolinieritas.

\section{b. Uji Heteroskedastisitas}

Tujuan asumsi

Heteroskedastisitas adalah untuk menguji apakah dalam sebuah model regresi terdapat ketidaksamaan varian dari satu pengamatan ke pengamatan yang lain. Jika varian berbeda, tersebut heteroskedastisitas. Menurut Santoso (2002:208), model regresi yang baik adalah tidak terjadi heteroskedastisitas. Model regresi yang bebas heteroskedastisitas dapat dilihat melalui charts scatterplot. Menurut Santoso (2002:210), dasar pengambilan keputusannya adalah sebagai berikut :

1) Jika ada pola tertentu seperti titik-titik (point-point) yang ada membentuk suatu pola tertentu yang teratur (bergelombang, melebar kemudian menyempit), maka terjadi heteroskedastisitas.

2) Jika tidak ada pola yang jelas, serta titik-titik menyebar di atas dan di bawah angka pada sumbu Y, maka tidak terjadi heteroskedastisitas.

\section{c. Uji Normalitas}

Tujuan asumsi normalitas data adalah untuk menguji apakah dalam suatu model regresi, variabel terikat, variabel bebas, atau keduanya mempunyai distribusi normal atau tidak. Model regresi yang baik adalah yang mempunyai distribusi data normal atau mendekati normal (Santoso, 2002:212).

Pada prinsipnya normalitas dapat dideteksi dengan melihat penyebaran data (titik), pada sumbu diagonal pada grafik atau dengan melihat histogram dari residualnya. Metode yang digunakan untuk menguji normalitas dengan melihat penyebaran dua (titik) pada sumbu diagonal dari grafik normalitas. Jika data menyebar pada garis diagonal, maka model regresi memenuhi asumsi normalitas. Namun jika data menyebar jauh dari garis diagonal atau tidak mengikuti arah garis diagonal, maka model 
regresi tidak memenuhi asumsi normalitas.

\section{Analisis Regresi Linier Berganda}

Model ini bertujuan untuk mengukur intensitas hubungan variabel-variabel independent terhadap variabel dependen (Dajan, 1999:325). Persamaan linier berganda untuk mengetahui hubungan antara variabel terikat dengan variabel bebas menggunakan rumus :

$\mathrm{Y}=\mathrm{a}+\mathrm{b}_{1} \mathrm{X}_{1}+\mathrm{b}_{2} \mathrm{X}_{2}+\mathrm{b}_{3} \mathrm{X}_{3}+\mathrm{b}_{4} \mathrm{X}_{4}+\mathrm{e}$ dimana :

$Y \quad=$ Variabel terikat

$X_{1}, X_{2}, X_{3}, X_{4}=$ Variabel bebas

$b_{1}, b_{2}, b_{3}, b_{4} \quad=$ Koefisien Regresi

\section{Interpretasi Koefisien Determinasi} $\left(\mathbf{R}^{2}\right)$

Koefisien determinasi

dimaksudkan untuk mengetahui tingkat ketepatan yang paling baik dalam analisa regresi, hal ini ditunjukkan oleh besarnya koefisien determinasi $\left(\mathrm{R}^{2}\right)$

antara 0 (nol) sampai dengan 1 (satu). Jika koefisien determinasi nol berarti variabel independen sama sekali tidak berpengaruh terhadap variabel dependen. Apabila koefisien determinasi semakin mendekati satu, maka dapat dikatakan bahwa variabel independen berpengaruh terhadap variabel dependen. Karena variabel independen pada penelitian ini lebih dari 2, maka koefisien determinasi yang digunakan adalah Adjusted $R$ Square (Imam Ghozali, 2001). Dari koefisien determinasi $\left(\mathrm{R}^{2}\right)$ ini dapat diperoleh suatu nilai untuk mengukur besarnya sumbangan dari beberapa variabel $\mathrm{X}$ terhadap variasi naik turunnya variabel $\mathrm{Y}$ yang biasanya dinyatakan dalam persentase.

Untuk mengetahui besarnya tingkat sumbangan (kontribusi) dari variabelvariabel bebas $\left(\mathrm{X}_{1}, \mathrm{X}_{2}, \mathrm{X}_{3}\right.$, dan $\left.\mathrm{X}_{4}\right)$ terhadap naik turunnya variabel terikat (Y) secara bersama-sama, yang dapat dilihat melalui koefisien determinasi dengan simbol $\mathrm{R}^{2}$ (Gujarati,1997:98).

Tabel

Interpretasi Nilai R (Korelasi)

\begin{tabular}{|l|l|}
\hline Besarnya nilai & Interprestasi \\
\hline Antara $0,800 \mathrm{~s} / \mathrm{d} 1,000$ & Tinggi \\
\hline Antara $0,600 \mathrm{~s} / \mathrm{d} 0,800$ & Cukup \\
\hline Antara $0,400 \mathrm{~s} / \mathrm{d} 0,600$ & Agak rendah \\
\hline Antara $0,200 \mathrm{~s} / \mathrm{d} 0,400$ & Rendah \\
\hline Antara $0,000 \mathrm{~s} / \mathrm{d} 0,200$ & Sangat rendah (tidak berkorelasi) \\
\hline
\end{tabular}

Sumber : Arikunto, Prosedur Penelitian Suatu Pendekatan Praktek. 1998:197.

\section{Analisis Uji Hipotesis}

Pengujian ini dilakukan untuk mengetahui pengaruh secara parsial antar variabel bebas terhadap variabel terikat.

Uji t hitung dengan rumus:

Keterangan:

$$
t=\frac{b j}{S b j}
$$

$\mathrm{t}=$ nilai $\mathrm{bj} \quad=$ koefisien regresi

Sbj $\quad=$ standar deviasi

Hipotesis statistiknya adalah sebagai berikut

a. Jika $t_{\text {hitung }}<t_{\text {tabel }}$, maka $\mathrm{H}_{\mathrm{o}}$ diterima dan $\mathrm{H}_{\mathrm{a}}$ ditolak

b. Jika $t_{\text {hitung }}>t_{\text {tabel }}$, maka $\mathrm{H}_{\mathrm{o}}$ ditolakdan $\mathrm{H}_{\mathrm{a}}$ diterima

Uji $F$

Uji F dengan rumus sebagai berikut: 


$$
F=\frac{R^{2}(n-k-1)}{K\left(1-R^{2}\right)}
$$

Keterangan:

$\mathrm{F} \quad=$ Nilai koefisien

R2 = Kefisien determinan

$\mathrm{n} \quad=$ jumlah sampel

$\mathrm{k}=$ jumlah variabel bebas

a. Menentukan $\mathrm{F}_{\text {tabel }}$ dengan tingkat signifikansi $(\alpha)$ sebesar $5 \%$ dan derajat kebebasan $\mathrm{df}_{1}=\mathrm{k}$, df2 $=(\mathrm{n}-$ $\mathrm{k}-1$ ).

b. Membuat keputusan hipotesis dengan membandingkan Fhitung dan Ftabel, yaitu:

- jika $F_{\text {hitung }}>F_{\text {tabel }}$ atau sig $<0,05$, maka $\mathrm{H}_{\mathrm{o}}$ ditolak atau $\mathrm{H}_{\mathrm{a}}$ diterima. Artinya, terdapat pengaruh yang signifikan dari variabel bebas (X) terhadap variabel terikat (Y) secara simultan.
- Jika $F_{\text {hitung }}<F_{\text {tabel }}$ atau sig $>0,05$, maka $\mathrm{H}_{\mathrm{o}}$ diterima atau $\mathrm{H}_{\mathrm{a}}$ ditolak. Artinya, tidak terdapat pengaruh yang signifikan dari variabel bebas (X) terhadap variabel terikat (Y) secara simultan.

\section{HASIL PENELITIAN \\ Karakteristik Responden}

Berdasarkan hasil penelitian yang telah dilakukan terhadap peneliti melalui penyebaran kuisioner kepada pelanggan yang datang ke Hotel Candisari Karanganyar-Kebumen. Maka dapat dikemukakan karakteristik dari informan penelitian sebagai berikut :

\section{Usia}

Hasil tabulasi deskripsi informan penelitian yang berhubungan dengan usia dapat dijelaskan sebagai berikut :

Tabel

Distribusi Frekuensi Usia Informan Penelitian

\begin{tabular}{|c|c|c|c|}
\hline No. & Usia (tahun) & Jumlah & Prosentase \\
\hline 1. & $<24-30$ tahun & 26 & $26 \%$ \\
\hline 2. & $>30-36$ tahun & 13 & $13 \%$ \\
\hline 3. & $>36-42$ tahun & 24 & $24 \%$ \\
\hline 4. & $>42-48$ tahun & 30 & $30 \%$ \\
\hline 5. & $>48$ & 7 & $7 \%$ \\
\hline & Jumlah & 100 & 100.0 \\
\hline
\end{tabular}

Sumber : Data primer diolah 2013

Berdasarkan di atas diketahui bahwa informan penelitian yang merupakan pelanggan Hotel Candisari Karanganyar-Kebumen yang paling banyak adalah informan penelitian dengan rentang usia $>42-48$ tahun yaitu sebesar $30 \%$, pelanggan pada usia ini pada umumnya yang sering menggunakan jasa hotel pada akhir tahun karena mereka lebih banyak mengisi liburan bersama keluargannya.

\section{Jenis Kelamin}

Hasil tabulasi deskripsi informan penelitian yang berkaitan dengan jenis kelamin dapat dijelaskan sebagai berikut :

Tabel

Distribusi Frekuensi Jenis Kelamin Informan Penelitian

\begin{tabular}{|r|l|c|c|}
\hline No. & Jenis Kelamin & Jumlah & Prosentase \\
\hline 1. & Laki-laki & 52 & $52 \%$ \\
\hline
\end{tabular}




\begin{tabular}{|c|c|c|c|}
\hline 2. & Perempuan & 48 & $48 \%$ \\
\hline & Jumlah & 100 & 100.0 \\
\hline
\end{tabular}

Sumber : Data primer diolah 2013

Berdasarkan di atas diketahui bahwa banyak untuk peneliti.

informan penelitian yang berjenis kelamin laki-laki sebanyak 52 informan penelitian atau $52 \%$ dan informan penelitian yang berjenis kelamin perempuan sebanyak 48 informan penelitian atau $48 \%$. Hal ini berarti informan penelitian yang paling banyak diteliti dan memberikan informasi yaitu informan penelitian yang berjenis kelamin laki-laki, dan laki-laki biasanya sebagai kepala keluarga yang memesan jasa pada hotel karena itu disini lakilaki memiliki banyak informasi yang

\section{Status Perkawinan}

Berdasarkan hasil penelitian komposisi status perkawinan responden menunjukkan komposisi yang ideal atau normal. Jumlah responden yang berstatus sudah menikah sebanyak 88 orang $(88 \%)$, jumlah responden, jumlah responden yang berstatus lajang/Belum menikah adalah sebanyak 12 orang (12\%), Selengkapnya dapat dilihat pada tabel berikut:

Tabel

Distribusi Frekuensi Status Perkawinan Informan Penelitian

\begin{tabular}{|l|l|l|l|}
\hline No. & Status Perkawinan & Jumlah & Prosentase \\
\hline 1. & Sudah Menikah & 88 & $88 \%$ \\
\hline 2. & Belum Menikah & 12 & $12 \%$ \\
\hline & Jumlah & 100 & 100.0 \\
\hline
\end{tabular}

Sumber : Data primer diolah 2013

Berdasarkan di atas diketahui bahwa informan lebih banyak yang berstatus perkawinan sudah menikah karena saat penelitian adalah waktu liburan Lebaran dan Tahun Baru, jadi kebanyakan yang berkunjung di Hotel Candisari Karanganyar-Kebumen adalah keluarga dan hanya sebagian kecil yang individual. Dapat disimpulkan bahwa informan yang datang dengan keluarga mempunyai status perkawinan yaitu sudah menikah.

\section{Pekerjaan}

Berdasarkan hasil penelitian komposisi status pekerjaan responden menunjukkan Jumlah responden yang berstatus sebagai pegawai swasta, negeri dan wirausaha. Responden pegawai swata sebanyak 65 orang (65\%), yang berstatus pegawai negeri sebanyak 7 orang $(7 \%)$, dan yang berstatus wirausaha sebanyak 28 orang $(28 \%)$, Selengkapnya dapat dilihat pada berikut:

Tabel

Distribusi Frekuensi Status pekerjaan Informan Penelitian

\begin{tabular}{|c|l|c|c|}
\hline No. & \multicolumn{1}{|c|}{ Status Pekerjaan } & Jumlah & Prosentase \\
\hline 1. & Pegawai Swasta & 65 & $65 \%$ \\
\hline 2. & Pegawai Negeri & 7 & $7 \%$ \\
\hline 3. & Wirausaha & 28 & $28 \%$ \\
\hline & Jumlah & 100 & 100.0 \\
\hline
\end{tabular}


Sumber : Data primer diolah 2013

Berdasarkan tabel di atas menjelaskan bahwa pegawai swasta lebih mendominasi pengunjung yang datang di Hotel Candisari Karanganyar-Kebumen, itu Karena pegawai swasta memiliki waktu liburan yang cukup panjang dibandingkan dengan pegawai negeri dan wirausaha. Pegawai negeri dan wirausaha mengikuti tanggal "merah" dan cuti bersama sedangkan pegawai swasta tergantung keinginan atasan mereka.

\section{Pendapatan}

Berdasarkan hasil penelitian komposisi pendapatan responden selengkapnya dapat dilihat pada tabel berikut:

Tabel

Distribusi Frekuensi Status pendapatan Informan Penelitian

\begin{tabular}{|c|c|c|c|}
\hline No. & Pendapatan & Jumlah & Prosentase \\
\hline 1. & $<3.000 .000$ & 7 & $7 \%$ \\
\hline 2. & $>3.000 .000-4.000 .000$ & 64 & $64 \%$ \\
\hline 3. & $>4.000 .000-5.000 .000$ & 15 & $15 \%$ \\
\hline 4. & $>5.000 .000$ & 14 & $14 \%$ \\
\hline & Jumlah & 100 & 100.0 \\
\hline
\end{tabular}

Sumber : Data primer diolah 2013

Hasil berdasarkan table di atas bahwa pendapatan $>3.000 .000-4.000 .000$ lebih banyak dibandingkan rate pendapatan yang lain. Kebanyakan yang mempunyai pendapatan berkisar $>3.000 .000-4.000 .000$ adalah pegawai swasta, dan berdasarkan hasil informan bahwa perusahaan swasta mereka sudah menengah keatas sehingga pendapatan informan berkisar $>3.000 .000-4.000 .000$.

\section{Kedatangan}

Berdasarkan hasil penelitian komposisi status pendapatan responden Selengkapnya dapat dilihat pada tabel berikut:

Tabel Distribusi Frekuensi Status Kedatangan Informan Penelitian

\begin{tabular}{|c|c|c|c|}
\hline No. & Status Pekerjaan & Jumlah & Prosentase \\
\hline 1. & Lebih dari sekali & 48 & $48 \%$ \\
\hline 2. & 1 kali & 52 & $52 \%$ \\
\hline & Jumlah & 100 & 100.0 \\
\hline
\end{tabular}

Sumber : Data primer diolah 2013

Berdasarkan hasil penelitian komposisi status responden menunjukkan bahwa jumlah responden yang berstatus sering berkunjung/lebih dari 1 kali berkunjung ke Hotel Candisari Karanganyar-Kebumen sebanyak 48 orang (48\%), dan yang berstatus baru menjadi new comers sebanyak 52 orang (52\%), ini menunjukan bahwa pada saat Lebaran dan Tahun Baru hotel banyak dipenuhi oleh new comers yang berarti bahwa mereka juga ingin merasakan bagaimana jasa yang ditawarkan oleh Hotel Candisari Karanganyar-Kebumen. 
Hasil Uji Instrumen

Uji Validitas

Tabel

Hasil Uji Validitas

\begin{tabular}{|c|c|c|c|c|}
\hline Variabel & Item & $\begin{array}{c}\text { Pearson } \\
\text { Corelations } \\
\end{array}$ & r Tabel & Keterangan \\
\hline \multirow{3}{*}{$\begin{array}{l}\text { Karakteristik } \\
\text { Individu }\end{array}$} & X1.1 & 0.823 & 0,196 & Valid \\
\hline & $\mathrm{X} 1.2$ & 0.470 & 0,196 & Valid \\
\hline & $\mathrm{X} 1.3$ & 0.426 & 0,196 & Valid \\
\hline \multirow{6}{*}{ Gaya Hidup } & $\mathrm{X} 2.1$ & 0.756 & 0,196 & Valid \\
\hline & $\mathrm{X} 2.2$ & 0.804 & 0,196 & Valid \\
\hline & X2.3 & 0.837 & 0,196 & Valid \\
\hline & $\mathrm{X} 2.4$ & 0.892 & 0,196 & Valid \\
\hline & $\mathrm{X} 2.5$ & 0.869 & 0,196 & Valid \\
\hline & $\mathrm{X} 2.6$ & 0.826 & 0,196 & Valid \\
\hline \multirow{6}{*}{ Persepsi } & X3.1 & 0.676 & 0,196 & Valid \\
\hline & X3.2 & 0.781 & 0,196 & Valid \\
\hline & X3.3 & 0.821 & 0,196 & Valid \\
\hline & X3.4 & 0.848 & 0,196 & Valid \\
\hline & X3.5 & 0.769 & 0,196 & Valid \\
\hline & X3.6 & 0.773 & 0,196 & Valid \\
\hline \multirow{3}{*}{ Situasi } & $\mathrm{X} 4.1$ & 0.819 & 0,196 & Valid \\
\hline & $\mathrm{X} 4.2$ & 0.903 & 0,196 & Valid \\
\hline & $\mathrm{X} 4.3$ & 0.884 & 0,196 & Valid \\
\hline \multirow{4}{*}{$\begin{array}{c}\text { Keputusan } \\
\text { Konsumen (Y) }\end{array}$} & Y1.1 & 0.930 & 0,196 & Valid \\
\hline & Y1.2 & 0.956 & 0,196 & Valid \\
\hline & Y1.3 & 0.945 & 0,196 & Valid \\
\hline & Y1.4 & 0.967 & 0,196 & Valid \\
\hline
\end{tabular}

Berdasarkan dari tabel di atas semua item pertanyaan, dapat digunakan (valid).

\section{Hasil Uji Reliabilitas}

\section{Tabel}

Hasil Uji Reliabilitas

\begin{tabular}{|c|c|c|}
\hline Variabel & Nilai $\boldsymbol{\alpha}$ & Keterangan \\
\hline $\mathbf{X}_{\mathbf{1}}$ & 0.783 & Reliabel \\
\hline $\mathbf{X}_{\mathbf{2}}$ & 0.910 & Reliabel \\
\hline $\mathbf{X}_{\mathbf{3}}$ & 0.870 & Reliabel \\
\hline $\mathbf{X}_{\mathbf{4}}$ & 0.839 & Reliabel \\
\hline $\mathbf{Y}$ & 0.964 & Reliabel \\
\hline
\end{tabular}

Sumber: data primer diolah, 2013

Berdasarkan data dari Tabel diatas, terlihat bahwa semua variabel mempunyai nilai $\alpha$ lebih besar dari 0,6. Hal ini menjelaskan bahwa seluruh item pertanyaan adalah reliabel. 
Artinya dalam setiap item pertanyaan dan pernyataan pada kuesioner penelitian benarbenar terjadi dan dialami oleh responden di lapangan.

Uji Asumsi Klasik

1. Hasil Uji Multikolinearitas

Tabel

Hasil Uji Multikolinieritas

\begin{tabular}{|c|r|r|c|}
\hline Variabel & $\begin{array}{c}\text { Nilai } \\
\text { tolerance }\end{array}$ & \multicolumn{1}{|c|}{ Nilai VIF } & Keterangan \\
\hline $\mathbf{X}_{\mathbf{1}}$ & 0.397 & 2.521 & Non multikolinieritas \\
\hline $\mathbf{X}_{\mathbf{2}}$ & 0.450 & 2.224 & Non multikolinieritas \\
\hline $\mathbf{X}_{\mathbf{3}}$ & 0.634 & 1.578 & Non multikolinieritas \\
\hline $\mathbf{X}_{\mathbf{4}}$ & 0.249 & 4.022 & Non multikolinieritas \\
\hline
\end{tabular}

Sumber: data primer diolah, 2013

Dari tabel di atas dapat diketahui bahwa semua variabel independen memiliki nilai VIF (Variance Inflating Factor) $>1$ dan nilai tolerance $<1$. Dari data ini dapat diartikan bahwa tidak terjadi gejala multikolinieritas antar variabel bebas.

\section{Uji Heteroskedasitas}

Dari gambar di bawah ini dapat dilihat bahwa terjadi pola titik-titik yang menyebar dan tidak teratur, serta titik-titik menyebar diatas dan dibawah angka 0 pada sumbu Y sehingga dapat disimpulkan bahwa tidak terjadi heteroskedastisitas pada data yang diperoleh dari responden.

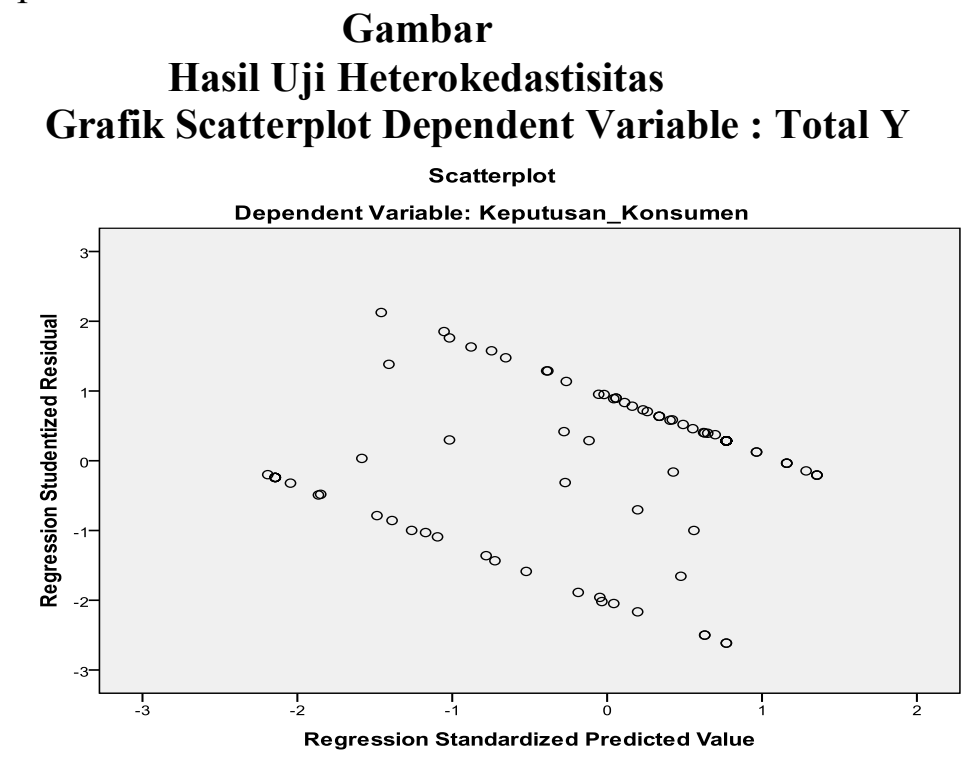

Sumber: data primer diolah, 2013

Dari Gambar grafik dapat dilihat bahwa terjadi pola titik-titik yang menyebar dan tidak teratur, serta titik-titik menyebar diatas dan dibawah angka 0 pada sumbu $\mathrm{Y}$ sehingga dapat disimpulkan bahwa tidak terjadi heteroskedastisitas pada data yang diperoleh dari responden. 


\section{Uji Normalitas}

Uji normalitas bertujuan untuk mengetahui apakah distribusi variabel terikat dan variabel bebas memiliki distribusi normal atau tidak.Pada normal probability plot, data dikatakan normal jika penyebaran titik-titik disekitar garis diagonal dan penyebarannya mengikuti arah garis diagonal. Hasilnya dapat dilihat pada gambar berikut:

\section{Gambar \\ Hasil Uji Normalitas \\ Grafik Normal P-P Plot of Regression Standardized Residual Dependent Variable: Total Y}

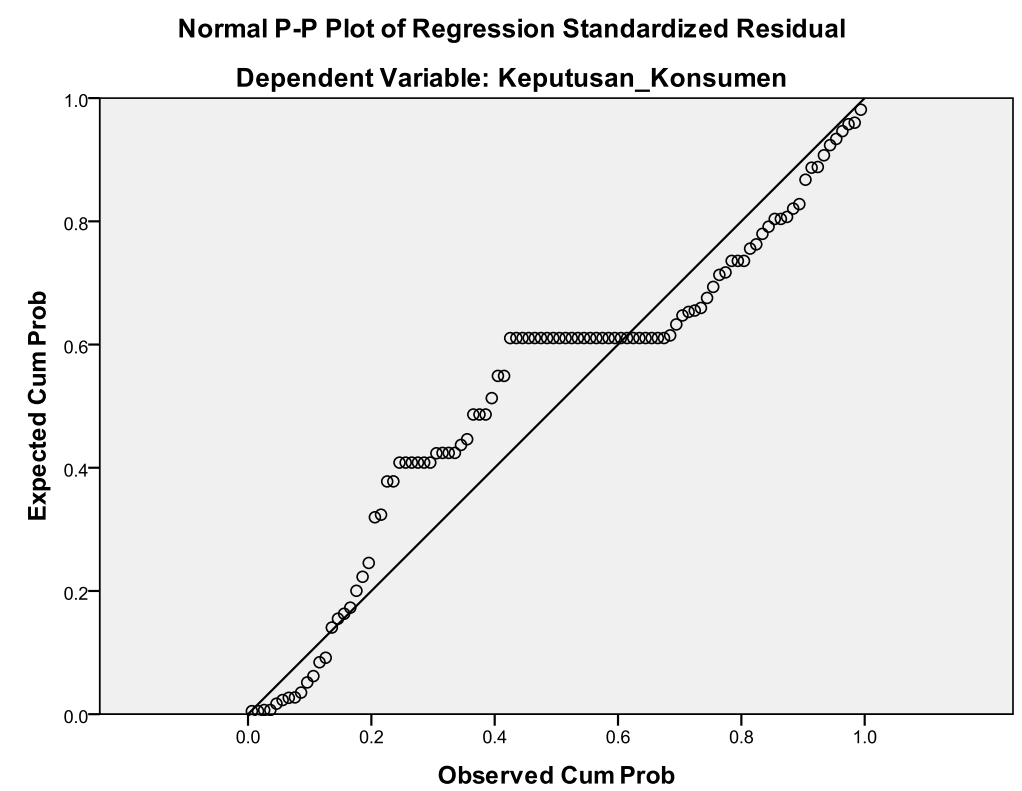

Berdasarkan gambar diatas, penyebaran titik-titik disekitar garis diagonal dan penyebarannya mengikuti garis diagonal.Jadi variabel terikat dan variabel bebas dalam penelitian ini normal.

\section{Hasil Analisis Regresi Linier Berganda}

Hasil yang diperoleh dari data analisis regresi berganda dapat dilihat pada tabel berikut ini:

\section{Tabel}

\section{Hasil Analisis Regresi Berganda}

\section{Coefficients $^{\mathrm{a}}$}

\begin{tabular}{|c|c|c|c|c|c|}
\hline \multirow[t]{2}{*}{ Model } & \multicolumn{2}{|c|}{ Unstandardized Coefficients } & \multirow{2}{*}{$\begin{array}{c}\begin{array}{c}\text { Standardized } \\
\text { Coefficients }\end{array} \\
\text { Beta }\end{array}$} & \multirow[b]{2}{*}{$\mathrm{t}$} & \multirow[b]{2}{*}{ Sig. } \\
\hline & B & Std. Error & & & \\
\hline (Constant) & 2.471 & 1.736 & & 1.423 & .158 \\
\hline karakteristik_Individu & -.220 & .189 & -.146 & -1.164 & .247 \\
\hline Gaya_Hidup & .079 & .086 & .108 & .910 & .365 \\
\hline Persepsi & .166 & .085 & .193 & 1.945 & .055 \\
\hline Situasi & 826 & .250 & .525 & 3.307 & .001 \\
\hline
\end{tabular}


Coefficients $^{\mathbf{a}}$

\begin{tabular}{|c|c|c|c|c|c|}
\hline \multirow[t]{2}{*}{ Model } & \multicolumn{2}{|c|}{ Unstandardized Coefficients } & \multirow{2}{*}{$\begin{array}{c}\text { Standardized } \\
\text { Coefficients } \\
\text { Beta }\end{array}$} & \multirow[b]{2}{*}{$\mathrm{t}$} & \multirow[b]{2}{*}{ Sig. } \\
\hline & $\mathrm{B}$ & Std. Error & & & \\
\hline (Constant) & 2.471 & 1.736 & & 1.423 & .158 \\
\hline karakteristik_Individu & -.220 & .189 & -.146 & -1.164 & .247 \\
\hline Gaya_Hidup & .079 & .086 & .108 & .910 & .365 \\
\hline Persepsi & .166 & .085 & .193 & 1.945 & .055 \\
\hline Situasi & .826 & .250 & .525 & 3.307 & .001 \\
\hline
\end{tabular}

a. Dependent Variable: Keputusan_Konsumen

Sumber: data primer diolah, 2013

Berdasarkan penghitungan analisis regresi linier berganda yang telah dilakukan menggunakan SPSS dapat disusun persamaan regresi sebagai berikut :

$$
Y=2.471-0.220 X_{1}+0.079 X_{2}+0.166 X_{3}+0.826 X_{4}+e
$$

Interpretasi model regresi adalah sebagai berikut :

1. Konstanta $(\mathrm{a})=2.471$

Menunjukkan nilai konstanta atau nilai tetap yang berpengaruh oleh variabel karakteristik individu, gaya hidup, persepsi, dan situasi. Artinya apabila karakteristik individu $\left(\mathrm{X}_{1}\right)$, gaya hidup $\left(\mathrm{X}_{2}\right)$, persepsi $\left(\mathrm{X}_{3}\right)$ dan situasi $\left(\mathrm{X}_{4}\right)$ sama dengan nol, maka keputusan konsumen (Y) sebesar 2.471 dengan asumsi variabel lain tidak berubah atau ceteris paribus.

2. $\mathrm{b} 1=-0,220$

Variabel Karakteristik individu dengan koefisien b $1=-0,220$, tanda negatif mengandung arti apabila nilai koefisien regresi 3 variabel lainnya tidak tetap, maka perubahan variabel Karakteristik Individu akan memberikan pengaruh yang searah terhadap keputusan konsumen dalam memilih hotel melalui internet marketing.

3. b $2=0,079$

Variabel Gaya hidup konsultasi dengan koefisien b $2=0,079$ tanda positif mengandung arti apabila nilai koefisien regresi 3 variabel lainnya tetap atau dalam keadaan ceteris paribus, maka perubahan variabel gaya hidup akan memberikan pengaruh yang searah terhadap keputusan konsumen dalam memilih hotel melalui internet marketing.

4. b $3=0,166$

Variabel Persepsi dengan koefisien b3 = 0,166, tanda positif mengandung arti apabila nilai koefisien regresi 3 variabel lainnya tetap atau dalam keadaan ceteris paribus, maka perubahan variabel persepsi akan memberikan pengaruh yang searah terhadap terhadap keputusan konsumen dalam memilih hotel melalui internet marketing.

5. $\mathrm{b} 4=0.826$

Variabel Situasi dengan koefisien b4 = 0.826, tanda positif mengandung arti apabila nilai koefisien regresi 3 variabel lainnya tetap atau dalam keadaan ceteris paribus, maka perubahan variabel situasi akan memberikan pengaruh yang searah terhadap keputusan konsumen dalam memilih hotel melalui internet marketing. 


\section{Uji Hipotesis}

\section{Uji t}

Uji t digunakan untuk mengetahui apakah variabel independen dan mempengaruhi variabel dependen. Berikut ini adalah tabel uji t

\section{Tabel}

\section{Hasil Uji t}

\section{Coefficients $^{\mathrm{a}}$}

\begin{tabular}{|ll|r|r|r|r|r|}
\hline Model & \multicolumn{3}{|c|}{$\begin{array}{c}\text { Unstandardized } \\
\text { Coefficients }\end{array}$} & \multicolumn{2}{c|}{$\begin{array}{c}\text { Standardized } \\
\text { Coefficients }\end{array}$} & \\
\cline { 3 - 5 } & & \multicolumn{1}{|c|}{ B } & Std. Error & Beta & \multicolumn{1}{c|}{ S } & \multicolumn{1}{c|}{ Sig. } \\
\hline 1 & (Constant) & 2.471 & 1.736 & & 1.423 & .158 \\
& karakteristik_Individu & -.220 & .189 & -.146 & -1.164 & .247 \\
& Gaya_Hidup & .079 & .086 & .108 & .910 & .365 \\
& Persepsi & .166 & .085 & .193 & 1.945 & .055 \\
& Situasi & .826 & .250 & .525 & 3.307 & .001 \\
\hline
\end{tabular}

a. Dependent Variable: Keputusan_Konsumen

Sumber : Data Primer, diolah 2013

1. Berdasarkan pada tabel IV-10 diatas, Variabel Karakteristik Individu $\left(\mathrm{X}_{1}\right)$ mempunyai nilai $\mathrm{t}$ hitungsebesar $-1,164$ dan $\mathrm{t}$ tabel sebesar 1,984 atau $\mathrm{t}$ hitung $<\mathrm{t}$ tabel sedangkan nilai signifikansinya sebesar $0,247>\alpha(0,05)$ jadi $\mathrm{H}_{1}$ ditolak yang artinya Karakteristik Individu $\left(\mathrm{X}_{1}\right)$ tidak berpengaruh secara signifikan terhadap Keputusan Konsumen dalam memilih hotel melalui internet marketing.

2. Berdasarkan pada tabel IV-10 diatas, Variabel Gaya Hidup $\left(\mathrm{X}_{2}\right)$ mempunyai nilai $\mathrm{t}$ hitungsebesar 910 dan $t_{\text {tabel }}$ sebesar 1,984 atau $t_{\text {hitung }}<$ $\mathrm{t}$ tabel sedangkan nilai signifikansinya sebesar $0,365>\alpha$ $(0,05)$ jadi $\mathrm{H}_{2}$ ditolak yang artinya Gaya Hidup $\left(\mathrm{X}_{2}\right)$ tidak berpengaruh signifikan terhadap Keputusan Konsumen (Y) dalam memilih hotel melalui internet marketing
3. Berdasarkan pada tabel IV-10 diatas, Variabel Persepsi $\left(\mathrm{X}_{3}\right)$ mempunyai nilai $t_{\text {hitung }}$ sebesar 1,945 dan $t$ tabel sebesar 1,984 atau $t$ hitung $<\mathrm{t}$ tabel sedangkan nilai signifikansinya sebesar $0,055>\alpha$ $(0,05)$ jadi $\mathrm{H}_{3}$ ditolak yang artinya Persepsi $\left(\mathrm{X}_{3}\right)$ tidak berpengaruh terhadap Keputusan Konsumen (Y) dalam memilih hotel melalui internet marketing

4. Berdasarkan pada tabel IV-10 diatas, Variabel Situasi $\left(\mathrm{X}_{4}\right)$ mempunyai nilai thitung sebesar 3.307dan $\mathrm{t}$ tabel sebesar 1,984 atau $\mathrm{t}$ hitung $>t$ tabel sedangkan nilai signifikansinya sebesar $0,001<\alpha$ $(0,05)$ jadi $\mathrm{H}_{4}$ diterima yang artinya Situasi $\left(\mathrm{X}_{4}\right)$ berpengaruh signifikan terhadap Keputusan Konsumen (Y) dalam memilih hotel melalui internet marketing.

\section{Uji F}

Tujuan dari uji $\mathrm{F}$ adalah untuk mengetahui seluruh variabel independen secara bersamasama mempengaruhi variabel dependen. 


\section{Tabel}

\section{Hasil Uji F/ Simultan}

\begin{tabular}{|ll|r|r|r|r|r|}
\hline Model & & Sum of Squares & Df & Mean Square & F & Sig. \\
\hline 1 & Regression & 125.868 & 4 & 31.467 & 16.126 & $.000^{2}$ \\
& Residual & 185.372 & 95 & 1.951 & & \\
& Total & 311.240 & 99 & & & \\
\hline
\end{tabular}

a. Predictors: (Constant), Situasi, Persepsi, Gaya_Hidup, karakteristik_Individu

b. Dependent Variable: Keputusan_Konsumen

Berdasarkan dari tabel IV-11 diatas, dengan nilai $\mathrm{F}$ hitung sebesar 16.126 lebih besar dari $F$ tabel sebesar 2,699 atau $F$ hitung $>F_{\text {tabel }}$ dan tingkat signifikasinya sebesar $0,000<0,05$ maka Ho di tolak yang artinya secara simultan variabel karakteristik individu $\left(\mathrm{X}_{1}\right)$, Gaya Hidup $\left(\mathrm{X}_{2}\right)$, Persepsi $\left(\mathrm{X}_{3}\right)$, dan Situasi $\left(\mathrm{X}_{4}\right)$, berpengaruh secara signifikan terhadap Keputusan Konsumen (Y).

\section{Interpretasi Koefisien Determinasi $\left(\mathbf{R}^{\mathbf{2}}\right)$}

Koefisien determinasi ini digunakan untuk mengetahui seberapa besar pengaruh variabel-variabel bebas memiliki pengaruh terhadap variabel terikatnya. Nilai koefisien determinasi untuk variabel bebas lebih dari 2 digunakan adjusted $\mathrm{R}$ square.

Tabel

Hasil Uji Koefisien Determinasi

\begin{tabular}{|l|l|l|l|l|l|}
\hline Model & R & R Square & $\begin{array}{l}\text { Adjusted R } \\
\text { Square }\end{array}$ & $\begin{array}{l}\text { Std. Error of the } \\
\text { Estimate }\end{array}$ & Durbin-Watson \\
\hline 1 & $.636^{\mathrm{a}}$ & .404 & .379 & 1.39688 & 1.869 \\
\hline
\end{tabular}

a. Predictors: (Constant), Situasi, Persepsi, Gaya_Hidup, karakteristik_Individu

b. Dependent Variable: Keputusan_Konsumen

Berdasarkan pada tabel IV-12 diatas, nilai R Squaresebesar 0,379 yang artinya variabel Karakteristik Individu $\left(\mathrm{X}_{1}\right)$, Gaya Hidup $\left(\mathrm{X}_{2}\right)$ dan Persepsi $\left(\mathrm{X}_{3}\right)$, Situasi $\left(\mathrm{X}_{4}\right)$ berpengaruh terhadap Keputusan Konsumen sebesar 0,379 atau 37,9 \% sedangkan sisanya $62,1 \%$ dipengaruhi oleh faktor lain baik jasa maupun variabel lain yang tidak di teliti dalam penelitian ini.

\section{KESIMPULAN}

1. Berdasarkan hasil perhitungan persamaan regresi, dapat disimpulkan bahwa variabel bebas yang terdiri Karakteristik Individu, Gaya Hidup , Persepsi , Situasi memiliki pengaruh signifikan secara simultan terhadap Tingkat Keputusan Konsumen. Terbukti diperoleh hasil dari analisis regresi berganda diperoleh kondisi yang menunjukkan bahwa $\mathrm{F}_{\text {hitung }}>\mathrm{F}_{\text {tabel }}$ maka dapat disimpulkan bahwa secara simultan (bersama-sama) variable $\mathrm{X}$ (Karakteristik Individu, Gaya Hidup, Persepsi, Situasi) berpengaruh terhadap Keputusan Konsumen Dalam Memilih Hotel Melalui Internet Marketing (Y).

2. Variabel secara parsial (satu per satu) tidak mempunyai pengaruh yang signifikan terhadap 
Keputusan Konsumen Dalam Memilih Hotel Melalui Internet Marketing (Y). Untuk mengetahui bahwa variabel terbukti, maka dalam pengujian ini digunakan uji $\mathrm{t}$ (t-test) yaitu membandingkan nilai $t_{\text {hitung }}$ dan $t_{\text {tabel. }}$. Menunjukkan bahwa setiap variabel (X), (Karakteristik Individu (X1), Gaya Hidup (X2), dan Persepsi (X3)) dalam penelitian ini mempunyai nilai $t_{\text {hitung }}$ lebih kecil daripada nilai $t_{\text {tabel }}$ dengan nilai signifikansi $>0,05$. Hal ini menunjukkan bahwa variabel (X) (Karakteristik Individu, Gaya Hidup ,dan Persepsi) secara parsial (satu per satu) tidak mempunyai pengaruh yang signifikan negatif terhadap Keputusan Konsumen Dalam Memilih Hotel Melalui Internet Marketing (Y), dan dalam penelitian ini variabel Situasi (X4) mempunyai nilai $t_{\text {hitung }}$ lebih besar daripada nilai tabel dengan nilai signifikansi $<0,05$ maka secara parsial variabel situasi (X4) mempunyai pengaruh yang signifikan positiff terhadap Keputusan Konsumen Dalam Memilih Hotel Melalui Internet Marketing (Y).

3. Berdasarkan analisis regresi berganda diketahui bahwa variabel situasi $\left(\mathrm{X}_{4}\right)$ merupakan variabel yang memiliki nilai Standardized Beta terbesar. Dengan demikian dapat disimpulkan bahwa hipotesis ketiga dalam penelitian ini yang menyatakan bahwa diduga variabel Situasi $\left(\mathrm{X}_{4}\right)$ berpengaruh dominan terhadap Keputusan Konsumen Dalam Memilih Hotel Melalui Internet Marketing (Y) terbukti kebenarannya.

4. Berdasarkan hasil penelitian bahwa hanya $40 \%$ responden memilih hotel melalui internet marketing, sedangkan $\quad 60 \% \quad$ responden memilih hotel secara direct atau secara langsung.

\section{SARAN}

1. Pengelola hotel diharapkan untuk dapat menjaga kinerja dan lebih meningkatkan kualitasnya sejalan dengan perkembangan kebutuhan dan harapan konsumen. Salah satu strategi yang dapat digunakan untuk hotel candisari dalam meningkatkan kualitas baik jasa maupun kinerjanya adalah dengan memperhatikan kebutuhan pelanggan yang diharapkan, misalnya gaya hidup, situasi, persepsi dan karakteristik individu.

2. Faktor Karakteristik Individu, perusahaan perlu perhatikan, karena itu Hotel Candisari sebaiknya lebih melakukan segmentasi dari segi pendapatan pelanggan. Hotel candisari harus bisa menjaga harga kamarnya sesuai dengan fasilitas yang diberikan sehingga bisa bersaing dengan pesaingnya dan pelanggan bisa menilai sendiri bagaimana kualitas yang terbaik dari hotel candisari.

3. Faktor Gaya Hidup, Hotel Candisari sebaiknya terus mengikuti trend gaya hidup pelanggan dengan mendesain sesuai dengan konsep yang menimbulkan sesuatu yang berbeda dari hotel lainnya, baik konsep etnik maupun modern.

4. Faktor Persepsi, disini hotel candisari harus bisa menjaga nama baiknya dengan cara menjaga kepercayaan yang diberikan oleh pelanggan dengan terus meningkatkan keamanan 
dan pelayanan yang diberikan oleh hotel candisari kepada pelanggan.

5. Faktor Situasi, Hotel Candisari yang sudah terletak pada lokasi yang strategis maka yang harus dilakukan oleh perusahaan sebaiknya mereka bisa membuat suasana yang baik seperti halnya Hotel Candisari meningkatkan keamanan tempat parkir bagi kendaraan pelanggan, sehingga pelaggan tidak merasa khawatir apabila mereka membawa kendaraan pribadi. Hotel Candisari selain menggunakan media internet juga harus melakukan promosi dari media cetak seperti Koran, banner dan spanduk ditempat keramaiam sehingga hotel dapat meluaskan pasarnya.

6. Melihat hasil penelitian bahwa keputusan konsumen untuk memilih hotel candisari yang berasal dari promosi internet masih belum maksimal,perlu dipikirkan untuk lebih memaksimalkan media internet sebagai sarana promosi ampuh dalam marketing modern. Pilihan menggunakan sarana internet dapat memaksimalkan pengenalan calon konsumen akan keunggulan.

\section{DAFTAR PUSTAKA}

Arikunto, Suharsimi. 2002. Prosedur Penelitian Suatu Pendekatan Praktek. Edisi Revisi V. Jakarta : Rineka Cipta.

Assauri, S. 2004. Manajemen Produksi dan Operasi. FEUI. Jakarta.

Asseal \& Henry ( 1998 ) . consumer Behavior and marketing action $.6^{\text {th }}$ edition. Cengage learning .Alma, Buchari, 2004, Manajemen Pemasaran dan Pemasaran Jasa, Edisi Revisi, Penerbit Alfabeta, Bandung.

Basu Swastha dan Irawan, 2005, Manajemen Pemasaran Modern, Edisi Kedua,. Cetakan Kedua, Penerbit: Liberty, Yogyakarta.

David L. Loudon And Albert J. Della Bitta, Consumer Behavior : Concept and Applications, McGraw-Hill Book Company, Third Edition, 1988.

Dini, 2005, Penerapan Pemasaran Pada Bidang Perhotelan, Malang

Engel, James F, Consumer Behaviour, Forthworth, Seventh Edition, 1993

Engel, james F , Blackwell, Roger D , dan Minard,Paul W, 1994 , prilaku konsumen , ali bahasa budianyto, Binarupa Aksara, Jakarta

Griffin, Jill. 2005. Customer Loyalty : Menumbuhkan Dan Mempertahankan Pelanggan, Penerbit Erlangga. Jakarta.

Keputusan Menteri Perhubungan R.I No. PM 10/PW-301/Phb.77 tanggal 12 Desember 
Kotler, Philip, 2002, Manajemen Pemasaran, Edisi Millenium Jilid 2, Prenhalliinso, Jakarta.

Kotler, Philip, dan Garry Amstrong, Dasar-dasar Pemasaran, Prenhallindo, Jakarta Ratminto, dan Winarsih, Atik Septi, 2005, Manajemen Pelayanan (Pengembangan Model Konseptual, Penerapan Citizen's Charter dan Standar Pelayanan Minimal), Pustaka Pelajar, Yogyakarta.

Kotler, P., dan Keller, K.L., 2008, Manajemen Pemasaran Edisi 12, Cetakan III, Alih Bahasa oleh Benyamin Molan, 5-24; 177-183.

Malhotra (2005:364) Maholtra, Naresh. K. 2005, Riset Pemasaran Pendekatan Terapan, PT. Indeks

Marzuki, 2005, Metodologi Riset, Ekonisia, Yogyakarta.

Mowen, J.C. and Minor, M.S.: 2001, Consumer Behavior, Upper Saddle River.

Rambat Lupiyoadi \& A. Hamdani. 2006. Manajemen Pemasaran Jasa; Salemba Empat, Jakarta

Setiadi, N. (2005). Perilaku konsumen. Jakarta.

Shiffman, Leon G. dan Kanuk, Leslie Lazar. 1997. Consumer Behaviour. New Jersey. Prentice Hall.

Singarimbun, Masri dan Soffian Effendi, 1995, Metodologi Penelitian Survai, Edisi Revisi, PT. Pustaka LP3ES, Jakarta.

Singgih, Santoso, 2002, Buku Latihan SPSS Statistik Parametrik, Elex Media Komputindo Kelompok Gramedia, Jakarta.

Solomon, M.R, \& Stuart, E.W. (2003). Marketing: Real People Real Choices, Ed.3. New Jersey : Prentice Hall International, Inc.

Sugiyono, 2009. Metode Penelitian Kuantitatif, Kualitatif dan $R \& D$, Bandung: Alfabeta.

Sugiyono. 2008, Metode Penelitian Bisnis, Alfabeta, Bandung.

Sugiyono, 2004. Metode Penelitian administrasi (edisi kelima), Bandung: Alfabeta. Kelompok Gramedia, Jakarta.

Shwu-ing $W u$, Assosiate Professor, Departement Of Bussiness Administration, National Chin-Yi Institute of Technology, No.35, Lane 215, Section 1, Chungshan Road, Taiping, Taichung, Taiwan 411, R.O.C 
Surat Keputusan Menteri Perhubungan R.I No. PM 10/PW-301/Phb.77 tanggal 12 Desember 1977.

Sutisna, 2003, Perilaku Konsumen \& Komunikasi Pemasaran, Edisi ketiga, PT. Remaja Rosdakarya, Bandung.

Tjiptono, Fandy,2005, Pemasaran.Jasa,Bayumedia : Malang. , 2002, Manajemen Jasa, ANDI, Yogyakarta. .2001.Strategi Pemasaran.Penerbit Andi:Yogyakarta. 2000. Strategi Pemasaran.Edisi 1. Yogyakarta: Andi Offset. 1998, Manajemen Jasa, Edisi Kedua, Yogyakarta: Andi Offset. . 1997. Strategi Pemasaran. Edisi kedua, ANDI, Yogyakarta.

UN. Convention Concerning Customs Facilities For Touring (1954)

Uma, Sekaran, 2006, Research Methods for Business, Terjemahan oleh Kwan Men You, Salemba Empat, Jakarta.

Zeithaml, Valeri A, 2003, Service Marketing, International Edition, McGraw Hill Company, New York.

http://furqonblumah.blogspot.com/2010/06/macam-jenis-marketing-dalam-bisnis.html http://onlinebusiness.sitekno.com/article/64463/jenis-atau-tipe-internet-marketing.html www. wikipedia.com, 2011.

Yurosie online news, 2011. 